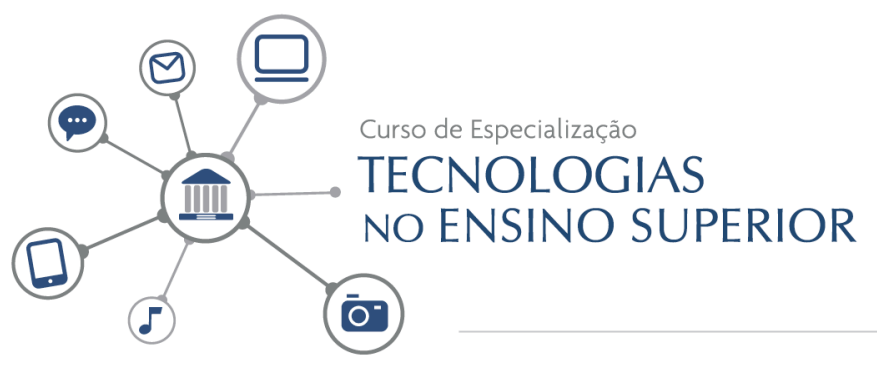

\title{
A Didática do Traço no Espaço Virtual: Origem e Visualidade
}

Trabalho de Conclusão de Curso

Coordenação Central de Educação a Distância PÓS-GRADUAÇÃO LATO-SENSU Tecnologias no Ensino Superior 


\title{
A Didática do Traço no Espaço Virtual:
}

Origem e Visualidade

\begin{abstract}
Trabalho de conclusão de curso apresentado à Coordenação do Curso de Especialização Tecnologias no Ensino Superior como requisito parcial para obtenção de título de Especialista em Tecnologias no Ensino Superior.
\end{abstract}

Orientador

Prof. Rosalia Maria Duarte

Coordenação Central de Educação a Distância Curso de Especialização Tecnologias no Ensino Superior

Rio de Janeiro Data: 11 de julho de 2016

Todos os direitos reservados. É proibida a reprodução total ou parcial do trabalho sem autorização do autor, do orientador e da universidade. 


\section{Perfil do aluno}

\section{Carlos Eurico Poggi de Aragão Júnior}

Graduou-se em Desenho Industrial e Comunicação Visual, pela PUC-Rio em 1984. Professor do Departamento de Artes e Design da PUC-Rio, desde 1997, lecionando em disciplinas de Desenho, principalmente, e Volume. Área de interesse: didática da imagem artística, História da Arte. Profissional de escultura e cenografia do carnaval do Rio de Janeiro de 1999 até 2014. Artista plástico com atuação diversificada no mercado, a saber: pintura, escultura, cenografia, desenho e audiovisual. Destaques para a performance na Arttrain'ee 2, Castelinho do Flamengo, 2002, e escultura cenográfica para o Eletric Forest Festival, Michigan, EUA, 2014. 


\section{Dedicatória}

Dedico este trabalho aos meus pais, pelo esforço de compreensão e dedicação que manteve a família unida durante toda uma vida. 


\section{Agradecimentos}

Meus sinceros agradecimentos à Professora Maria Lilia Simões de Oliveira pela paciência com que conduziu as mediações no Ambiente Virtual de Aprendizagem. Meus sinceros agradecimentos à Professora Rosalia Maria Duarte pela generosidade na discussão da proposta de didática e pela clareza com que conduziu a orientação do Trabalho de Conclusão de Curso desde o início até os detalhes finais. 


\section{Resumo}

Este trabalho identifica e analisa um problema de repertório cultural entre estudantes de artes visuais e propõe uma abordagem da didática da imagem artística em geral, cujo objetivo é oferecer estratégias de compreensão crítica e criativa das narrativas visuais atuais na sua relação com a História da Arte. A imagem artística é definida e entendida como desenho que se forma e se expressa através do traço, cuja interpretação decorrente de suas qualidades e de seus sentidos visuais pode gerar diversas inserções e narrativas na cultura como um todo e, especialmente, na cultura digital. O conceito de traço é estabelecido, metodologicamente, pelo seu caráter como índice de uma realidade, essencialmente, assim como signo, símbolo e, na totalidade da imagem, como espaço fotográfico, incorporando as possibilidades digitais como meio de sua investigação por metadados. Partindo de uma longa experiência didática com estudantes, o trabalho analisa a prática do traço indiciático e do suporte pictórico, para estabelecer as possíveis relações com a fotografia, pintura, escultura e com qualquer imagem artística presente na internet. O desenvolvimento desta didática da imagem artística pretende a criação de pontes temáticas e tecnológicas, definindo o presente e o passado como processos em registros contínuos, enquanto revela a História da Arte como uma atualidade indissociável do fazer artístico. $\mathrm{Na}$ análise final, são propostas estratégias didáticas, a serem implementadas em diferentes molduras possíveis no âmbito das tecnologias digitais, para favorecer uma compreensão da arte e de suas operações técnicas, permitindo assim um possível entrelaçamento de visões de mundo e ideias presentes na origem de cada traço.

\section{Palavras-chave:}

Imagem Arte Traço Índice Fotografia 


\section{SUMÁRIO}

\section{Introdução}

1. A centralidade da imagem na cultura digital e suas consequências

2. A formação básica que o estudante de arte precisa ter

3. Referenciais teóricos e abordagens didáticas no ensino de desenho

3.1 Uma conceituação didática do traço

3.2 O traço e a representação de figura humana

3.3 O traço, a representação de espaço e o plano pictórico

4. Propostas para um Ambiente Virtual de Aprendizagem

4.1 Blogger - Blog para exposição de conteúdo - Conceituação de traço

4.2 Facebook - Página de Grupo Público - Discussão sobre traço

4.3 Youtube - Canal de vídeos - Análise de trajetórias artísticas e históricas

4.4 Atividades

4.4.1 Ambiente virtual I - Traço: matéria e signo do ato pictórico

4.4.2 Ambiente virtual II - Traço: anatomia e representação humana

4.4.3 Ambiente virtual III - Traço: ilusão e codificação espacial

4.4.4 Ambiente virtual IV - Traço: conceito cultural e artístico

5. Mapa Conceitual da Ação Didática

Conclusão

Referências Bibliográficas

Índice de Ilustrações 


\section{Introdução}

Vivemos em uma era onde valores estéticos e comportamentais são colocados visualmente diante nós por torrentes de narrativas mercadológicas, repletas de mensagens subliminares que, de forma quase instantânea, inserem julgamentos em nossas expectativas diárias, numa disputa pela atenção, pelo olhar, pela escolha. Nos paises com tecnologia da informação e comunicação muito desenvolvidas, a incorporação desses valores tem uma importância e uma naturalidade difíceis de serem avaliadas e até percebidas. A capacidade para discriminar o que vemos - a visão crítica e seletiva desenvolvida em consciências familiarizadas com as dinâmicas de valores culturais em jogo nas imagens midiáticas - não é um ensinamento oferecido de forma aberta e gratuita. Trata-se, de um modo geral, apenas de escolhas em camadas de narrativas, que sobrepondo a lógica de uma contra a outra, apresentam em poucos minutos valores que servem para reforçar as identidades que interessavam à priori. As consequências dessa realidade, facilmente percebidas em comentários de estudantes da PUC-Rio, também aparecem nos discursos políticos que se estruturam na sociedade, quando a disputa na cultura visual passou a questionar as razões históricas sem o devido contexto artístico, sob justificativas de desvios morais e éticos da atualidade.

A expressão social e política que poucos indivíduos organizados em rede podem atingir, em pouquíssimo tempo, demonstra claramente o poder tecnológico que está sendo disponibilizado para as pessoas via mercado. A capacidade de conexão dos diversos grupos sociais, que antes dependiam dos canais governamentais para a construção de valores visuais coletivos, possibilita que agora dialoguem entre si, de forma completamente independente. Aqueles que acompanham as narrativas e visualidades desse processo cultural diário, urbano e global, estão cientes dos seus rumos e valores sociais. Através da obsolescência programada de produtos e serviços, com o intuito de cativar mais e mais clientes, e multiplicar a audiência, o mundo das estratégias virtuais de soluções de comunicação lança mão de todo tipo de recurso audiovisual imaginável.

Em meio ao natural esforço econômico de empresas e profissionais para ganhar a atenção do público, o espaço público tem sua visualidade transformada por novas formas de entretenimento, fazendo nascer hábitos e fabricando escolhas 
que direcionam culturas inteiras, enquanto muitas outras realidades culturais são absorvidas em narrativas que as reestruturam e as recodificam.

Quase tudo que é oferecido visualmente ao grande público em termos de cultura artística está organizado dentro desta moldura tecnológica e mercadológica. As referências acadêmicas e institucionais, mesmo mantendo os seus status cultural e credibilidade, estão niveladas no imaginário popular, alimentado pela cultura digital, a todo tipo de manifestação e expressão visual. Por isso, é inevitável que a compreensão dos valores estéticos expressos em imagens artísticas seja afetado.

Os jovens, em sua imensa maioria, têm sua jornada cultural diária atravessada pelas experiências visuais da web. A facilidade de acesso a grandes volumes de informação histórica, quando roteirizadas em pequenas obras audivisuais sobre generalidades e curiosidades do mundo da Arte, serve apenas para entreter. A necessidade da agilidade visual, e uso adequado dos recursos técnicos da plataforma digital, limitam à priori, mas não definitivamente, o valor artístico e o discurso estético que pode ser estruturado em uma narrativa compactada.

\section{A centralidade da imagem na cultura digital e suas consequências}

Há poucos meses de completar duas décadas como professor de desenho artístico da PUC-Rio, avalio que as mudanças tecnológicas que tive a oportunidade de acompanhar nos últimos anos, principalmente o aumento da facilidade de acesso à informação, não estão ajudando a desenvolver a cultura artística geral dos estudantes, pelo menos até aonde posso observar. Não diria que houve um aumento do interesse pela compreensão da experiência em arte e cultura narrada em livros físicos, por conta do aumento da leitura e das referências bibliográficas presentes na internet. A mudança mais significativa, na minha opinião, poderia ser o desinteresse pela imagem reproduzida em meios físicos, em virtude da rapidez e do baixo custo do mundo compactado oferecido pelos dispositivos móveis. A experiência estética e filosófica do mundo real, envolvendo as diferentes formas de imersão cultural, e não apenas os livros 
relacionados ao interesse de cada um, está sendo exposta a uma recodificação de valores visuais na rotina da cultura digital.

Importantes referências da História da Arte Moderna, cujas experiências visuais produzidas foram incorporadas e banalizadas no oceano midiático contemporâneo, tendem a perder a sua excepcionalidade estética pela ausência da compreensão de contexto exigida. Mesmo sendo parte do imaginário cultivado por muitas culturas digitais, ou mesmo a sua própria origem visual, as possibilidades de uma apresentação tecnológica que as explique e justifique, como processos criativos de complexa estruturação e, assim, permitir novas atitudes na interação com a imagem virtual, no momento, não parecem possíveis.

Observando o conteúdo de desenho e arte na web, e o comportamento do público em geral e dos estudantes, é possível identificar as leituras e interpretações que fazem das imagens nas pequenas postagens de imagens e obras audiovisuais. Inicialmente, não há como uma pessoa, sem uma abrangente, e minimamente investigativa, vivência artística com a física de diferentes materiais, avaliar o que vê. Porém, o maior desafio, a meu ver, é a contextualização dos caminhos culturais que produziram as obras mais conhecidas. Ou seja, há um desafio didático, evidentemente ainda não colocado, que se traduz na constatação da dificuldade dos estudantes de entender imagens artísticas conhecidas. Quando são imagens que desenvolvem questões de desenho, porém, as consequências para a vida acadêmica e profissional podem ser decisivas.

Outro ponto importante é a má compreensão das experiências técnicas e trajetórias artísticas que determinaram as atitudes e decisões criativas dos movimentos artísticos dos séculos XIX e XX. Diante dos discursos promocionais de exposições e eventos, elegendo estéticas pontuais, que se cruzam na cultura mainstream e veiculam significados fabricados pelo senso comum, realidades e originalidades artísticas são reduzidas a palavras de ordem sobre como devem ser a arte e o artista na atualidade. Misturado a este caldo cultural estão, para piorar ainda mais, os julgamentos de valor monetário de obras e objetos, cuja dinâmica de mercado em momento algum pode ser a tradução de uma realização artística. Certas distorções artísticas mercadológicas em particular ganham ares de absurdo, 
quando envolvem celebridades sem nenhum significado em artes visuais além do pertencimento à cultura popular.

Observando este contexto de sobreposição desordenada de sentidos, valores e significados artísticos díspares, não é de surpreender o julgamento superficial do grande público, quando se aventura além da informação repetida pelos canais de mídia. Fazendo todas as ressalvas às manifestações de gosto pessoal, a dificuldade enfrentada pelo estudante de Artes e Design em se localizar neste caos sensorial é totalmente justificada.

Contudo, deve-se destacar o impacto da espetacularização da informação visual que é veiculada nos ambientes virtuais da web, em particular, e na cultura em geral. A consequência inegável deste processamento industrial da imagem artística e de seu contexto histórico é uma espécie de "pasteurização" da percepção do passado. Esta face tecnológica da sociedade está levando inevitalvelmente a construções lógicas equivocadas sobre a arte do passado, ampliando a desconexão do presente com a narrativa original da imagem artística. Esta dinâmica não é indesejada porque é vista como uma parte do natural avanço do digital sobre os espaços e os recursos institucionais. Por isso, não é percebida como um achatamento de experiências artísticas nem como desconexão de sensibilidades das nuances do conhecimento, mas simplesmente como conhecimento artístico digitalizado.

Vale ressaltar que o processo tecnológico descrito acima não tem um impacto negativo naquelas pessoas que já possuem uma aprofundada formação estética, cultura artística, compreensão de imagens e domínio do uso da interface digital. Para estas, é preciso deixar bem claro, todo avanço industrial no sentido de facilitar o acesso ao universo da arte é mais uma janela cultural tecnológica a ser explorada. O problema na compreensão daquilo que é visualizado como arte, em dispositivos diversos, está na falta de educação artística de uma ampla parcela da população com acesso à internet. Pela minha experiência, já ficou muito claro que a mera apresentação tecnológica de volumosa informação visual artística não educa. Será preciso uma intervenção didática na forma de entender as imagens e desenhos, que possibilite uma ruptura na superficialidade do sistema 
mercadológico de consumo de ideias visuais, através de sucessivas ampliações do ato de simplesmente olhar.

\section{A formação básica que o estudante de arte precisa ter}

O perfil das pessoas que procuram os cursos de artes e design varia muito, mas a ausência de uma cultura artística mais aprofundada, eu diria, é geral. A percepção do universo da arte pela visão do senso comum, sem a intimidade maior que se esperaria de um estudante com interesse na área, é a regra. Todavia, a ação didática necessária para uma mudança essencial neste contexto, nada tem a ver com simples trabalhos pontuais de organização e apresentação de informação visual e textual online, visando superficiais explicações de obras de artes e artistas em suas trajetórias históricas. Isso já existe no fluxo audiovisual ininterrupto do universo digital, mas da forma como descrevi anteriormente: colchas de retalhos históricos da arte em sofisticadas molduras técnicas.

A ação necessária para ampliar a formação estética dos estudantes, bombardeados pelos hipnotizantes e caleidoscópicos cenários compactados da internet, poderá ter resultado prático através de uma ação didática que possibilite uma compreensão da formação das imagens. Trata-se de ensinar abordagens fundamentais para que o estudante desenvolva um conhecimento próprio das imagens artísticas, em geral, e de apontar a importância dos desenhos que estruturam as expressões artísticas atuais e históricas. É preciso oferecer a eles a possibilidade de conhecer de que forma as particularidades da construção da imagem artística formam o básico de uma linguagem visual, que precisa ser conhecida por todos que trabalham com imagem. Como se fosse o ensino de uma "língua franca" da atualidade, qualquer compreensão adicional das qualidades e valores expressados por imagens artísticas provavelmente mudaria a postura de simples expectadores, dos estudantes, ao que a internet os apresenta. Mas como fazer isso?

A transformação do natural interesse coletivo por generalidades artísticas em uma outra forma de olhar as imagens e pensá-las pode gerar um encadeamento de compreensões que venha a revelar outras maneiras de apreciar a própria História da Arte. A "consciência da estrutura de uma imagem", assim como a 
“consciência da operação de representação que gerou uma imagem”, e também a "consciência das narrativas culturais que comandam a percepção de uma imagem" são fundamentos que considero mínimos para qualquer estudante que esteja concluindo qualquer um dos cursos do Departamento de Artes e Design. No meu entendimento, uma pessoa que pretenda trabalhar com imagem, nas inúmeras áreas relacionadas, deveria ter estas três "consciências" muito bem desenvolvidas.

Parece-me muito claro que um curso superior com foco em imagem não tem como construir uma experiência acadêmica relevante, sem uma didática que ofereça uma estratégia mínima para o estudante julgar o que vê nos meios de comunicações atuais. Diria, inclusive, que o volume massivo de narrativas visuais praticamente impõe uma leitura única através das superposições de lógicas estetizantes do mercado. Limitada pelos parâmetros de consumo industrial dominante, essa leitura única pela cultura tecnológica da máquina sempre mais atual, se redefine apenas pelas nossas repetições de usos e escolhas, assim como dos usuários associados a nós pelas mesmas escolhas. Não é razoável que um estudante que pretenda ser um profissional da imagem permaneça, por causa do "looping infinito" do consumo, incapaz de apontar a origem, os usos e a estrutura técnica, mesmo de forma generalizada, dos diversos tipos de imagens e desenhos artísticos presentes na internet.

\section{Referenciais teóricos e abordagens didáticas no ensino de desenho}

As teorias e os métodos adotados nas abordagens educacionais e na crítica de arte são muitos, assim como muitos são os propósitos definidos em seus discursos. Como o foco deste trabalho não é uma construção teórica sobre arte, mas uma estratégica didática que possibilite aos estudantes desenvolver um olhar mais consciente sobre imagem e desenho na sua cultura, a experiência dos meus anos de prática pedagógica é fundamental nas minhas escolhas teóricas e metodológicas. Os muitos textos existentes formam um imenso mosaico histórico de abordagens possíveis da história da cultura e da arte nos quais sempre me apoiei para organizar as atividades das minhas disciplinas. As propostas de ações didáticas pretendidas, neste trabalho, deverão ser elaboradas a partir dos resultados explorados por um método de compreensão da informação visual, 
combinando a minha experiência como professor e artista, com algumas importantes e conhecidas análises da estrutura da imagem artística. Estas análises, quando relacionadas entre si e contextualizadas, historicamente e culturalmente, podem definir criteriosas perguntas e uma série de reflexões que, resumidas em um passo a passo, eu definiria como o "ritual pessoal do olhar inteligente".

Um texto primordial da cultura moderna que estabeleceu uma primeira análise da imagem artística foi livro de Wassily Kandinsky (Edições 70, 1996), "Ponto, Linha, Plano". O artista e teórico da Bauhaus propos um estudo abstrato dos elementos que, na visão dele, compõem uma pintura, o ponto e a linha, para depois relacioná-los com o plano, a superfície material do quadro. $\mathrm{Na}$ apresentação escrita por Philippe Sers, percebe-se a dificuldade de uma análise entremeada por considerações subjetivas que tentam evitar a fria dissecação da forma: "Daqui nascem as advertências constantes acerca da importância das ressonâncias interiores próprias dos elementos, e, para utilização desses elementos, o imperativo de se voltar sempre ao valor espiritual,...” (p.16). O vício de origem, aqui, é a indução do julgamento individual através de uma suposta percepção universal da imagem.

Pesquisando trabalhos relacionados na web, encontrei o arquivo digital do trabalho da professora Flavia Simonini Paradella, da UNESA, Universidade Estácio de Sá, com o título "Criação da Forma" (2011). Basicamente, ela define os "elementos visuais" que constituem uma linguagem visual através da "ciência da arte" tentada por Kandinsky. Os conceitos elaborados por ela são bastante objetivos e focados no ensino de design, demonstrando uma visão didática bem difundida. A importância de assinalar trabalhos como esse é apontar referências da didática estabelecida, de modo que, assim que a minha proposta for colocada, ela possa ser percebida pela sua contribuição à compreensão da imagem artística.

Outra obra teórica que subsidia as reflexões apresentadas neste trabalho é “Arte e Percepção Visual”, de Rudolf Arnheim (Editora Pioneira, 2000), que, além de abordar os aspectos formais da imagem artística, estabelece relações psicológicas entre os elementos estruturais da imagem e as percepções das obras analisadas. Nesta obra, destaco a contextualização cultural da intenção do artista e suas soluções, como um aspecto necessário para compreensão de qualquer 
imagem. Porém, as abordagens elaboradas nos textos de Rudolf Arnheim demandam uma vasta experiência visual com obras de arte e aprofundado conhecimento iconográfico. Pré requisitos com os quais não poderei contar para construir a minha proposta de ação didática, visto que o meu objetivo é desenvolver uma estratégia dirigida para o público das minhas disciplinas.

Seguindo com as pesquisas na internet sobre publicações que poderiam ser relacionadas ao que pretendo, encontrei o trabalho de Fábio Salum, UNISUL, $1^{\circ}$ Seminário Nacional; Discurso, Cultura e Mídia (2002). O que me interessou na abordagem do autor foi que, partindo das teorizações de Wassily Kandinsky sobre os elementos formadores da pintura, citando Fayga Ostrower, Konrad Fiedler e Wilhelm Worringer, ele estabelece um paralelo com o recorte e a fragmentação na fotografia. Para fazer uma ligação poética entre os elementos pictóricos e a imagem indiciária da fotografia, Fábio Salum usou como apoio um livro que será central na minha pesquisa: "O Ato Fotográfico e outros ensaios", de Philippe Dubois (Papirus, 1993). Apesar do alinhamento de importantes reflexões sobre os conceitos estruturais da imagem artística, o citado trabalho não arrisca apontar nenhum aspecto formal como possível fio condutor de pensamentos plásticos comuns, a linguagens visuais modernas e contemporâneas. Contudo, o fato de Fábio Salum ter usado imagens fotográficas aleatórias, capturadas de seu computador para completar a sua reflexão, é muito significativo para mim porque isso aproxima o trabalho dele da minha proposta.

\subsection{Uma conceituação didática do traço}

Os textos citados acima são exemplos de trabalhos importantes, abordando elementos visuais e conceituais dos quais preciso como referência para distinguir a minha visão de didática da imagem artística. $\mathrm{O}$ que me pareceu ter escapado por entre as reflexões do texto de Fábio Salum, envolvendo a espiritualidade e o fazer de Kandinsky, e as implicações estéticas do corte fotográfico, na definição de espaço pictórico e espaço fotográfico, foi a questão da intenção artística. Quando citou Wilhelm Worringer, pareceu-me quase obrigatório ter mencionado um conceito fundamental, elaborado por Alois Riegl, para a história das culturas: vontade artística (kunstwollen). Diante da perspectiva de tentar estabelecer relações e análises entre os diferentes signos produzidos por diferentes origens - 
habilidades artesanais, máquinas e suas culturas -, fico a imaginar se haveria algum impedimento filosófico para pensar a estrutura da imagem artística através da formação da sua própria realidade visual, ou seja, a sua característica e origem.

Fundamentalmente, não concordo com o entendimento dos autores citados por dois aspectos. Primeiro, as unidades apontadas como formadoras da imagem artística podem ter origens e apresentações indistinguíveis das funções semânticas que os autores propuseram. Forçar uma identificação dessas "unidades germinadoras" em toda e qualquer obra pictórica seria de um artificialismo completamente sem sentido, com o único propósito de justificar teorias, reflexões e métodos. Segundo, é fácil constatar que tais "manuais" para a percepção da imagem artística induzem e limitam a compreensão da relação da imagem com o mundo e a cultura da época. Um alerta para esta "armadilha" pode ser encontrado no livro "Arte e Percepção Visual”, de Rudolf Arnheim (Editora Pioneira, 2000), ainda na Introdução. Amparado na minha experiência pedagógica e artística, posso afirmar que não há como exercer um "controle" sobre a percepção e a interpretação de imagens artísticas, ao ponto de dissecá-las cientificamente e universalmente, e ainda advinhar seus futuros desdobramentos culturais. Ou seja, não há como estabelecer uma tradução única de uma obra visual, porque os seus elementos estruturantes podem mudar de significado com o tempo, a cultura etc. Contudo, o necessário esforço de compreensão com fins históricos e didáticos, com ambições educacionais, é imensamente válido.

A proposta de ação didática que pretendo definir tem sua origem em uma vasta experiência pedagógica, resultante de séries de atividades e trabalhos desenvolvidos em sala de aula por mais de dez anos. A relação teórica que eu talvez pudesse colocar, para apontar referências interpretativas para o meu pensamento como professor, seria com as metodologias derivadas da Teoria da Pura Visibilidade, de Konrad Fiedler (Visor, 1991). Contudo, ao circunscrever meu objetivo pedagógico às táticas de abordagem das imagens artísticas e desenhos, que inundam o imaginário dos estudantes através da internet, principalmente, o universo visual a ser pesquisado já se apresenta inteiramente nivelado como imagens digitais. Mesmo que a imagem artística digital apresente pequenos textos e links sobre a técnica, contexto sociopolítico, biografia do autor, 
comentário crítico, o desafio didático é capacitar o aluno a discernir o que vê. Nesse sentido, o "achatamento digital" da informação visual que é disponibilizada na internet deve ser observado como um fator interpretativo essencial.

Quando mencionei o livro "O Ato Fotográfico e outros ensaios", de Philippe Dubois (1993), como o principal apoio teórico e metodológico à didática pretendida, já deixava claro que a imagem artística e o desenho seriam investigados, todos, dentro da moldura técnica da fotografia. Partindo da constatação de que a totalidade das imagens artísticas na internet é codificada visualmente pela fotografia e pela reprodução digital desta, a compreensão dos conceitos que se tornaram fundamentais para a cultura ocidental através da fotografia deverá ser um aspecto central da pesquisa. $\mathrm{Na}$ verdade, as outras abordagens da ação didática serão sempre complementares em relação aos elementos fotográficos estruturantes, enquanto o esforço de compreensão da imagem for através do fluxo visual da internet. Contudo, gostaria de estender o olhar pesquisador para as situações em que o estudante envolvido com imagens possa atuar com mais consciência crítica, seja na rua, na galeria de arte do seu bairro, nos museus e eventos.

Apesar da fotografia digital não ser contemplada pelas reflexões do livro, “O Ato Fotográfico e outros ensaios", de Philippe Dubois, que é de 1993, todas as questões apresentadas pelo traço fotográfico tradicional, ou seja, o signo indicial estudados como ícone, índice e símbolo, na famosa tricotomia peirciana (Charles Sanders Pierce, filósofo e semiótico americano, 1839-1914), assim como o recorte do espaço fotográfico, - continuam válidas em fotos digitais. Porém, o caráter documental da fotografia como um corte na realidade não pode ser integralmente atribuído à reprodução fotográfica digital por causa de sua natureza tecnológica facilmente manipulável. Dito isso, está claro que os valores visuais a serem observados deverão sempre ter as referências tecnológicas como participantes das análises. Porém, navegando no imagético fluxo da cultura digital, onde as questões de desenho se misturam com infindáveis reproduções digitais de milhares de realidades vividas e produzidas, possíveis e impossíveis, qual seria uma reflexão válida a ser tentada? 


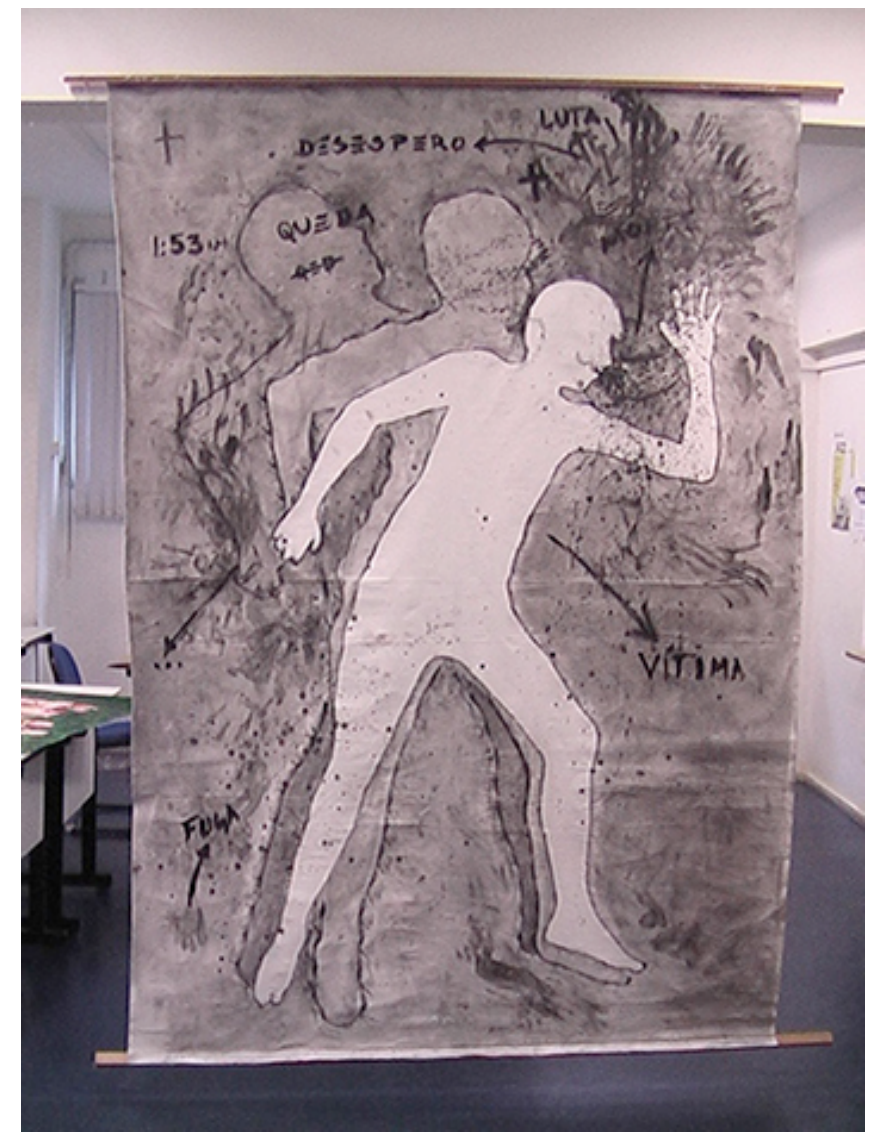

Trabalho de Sombra, Caligrafia e Gestualidade. Aula de Desenho de Observação. Anos 2000. Imagem de arquivo pessoal do professor. Fig. 1

Entre as principais atividades que faziam parte do programa da minha disciplina de desenho de observação, havia uma que foi elaborada especialmente para desenvolver a compreensão dos conceitos de ícone, índice e símbolo. Chamava-se "Sombra, Caligrafia e Gestualidade", deveria ser executado em preto e branco, e ao estudante era proposto a reprodução da própria sombra real, de qualquer tamanho, com ou sem distorção, assim como diversos usos de traços e manchas a serem produzidas pelas mãos, braços, pés e/ou o corpo inteiro. Após as primeiras tentativas dos estudantes, tinha início várias séries de questionamentos para se tentar definir a natureza das imagens por eles produzidas. Era comum os estudantes enfrentarem sérias dúvidas sobre como realizar a atividade, e somente com muitas análises das imagens apresentadas, a percepção das origens dos traços, manchas e linhas começava a ganhar significado. Para chegar a este ponto, eu sempre fazia uma pergunta básica a qualquer coisa que os estudantes tivessem feito: “Quais as origens destes traços?”. Somente após chegarmos a estas respostas, muitas vezes através de deduções pelas características das formas 
visíveis, passava-se às análises dos resultados quanto aos sentidos e significados pretendidos e alcançados.

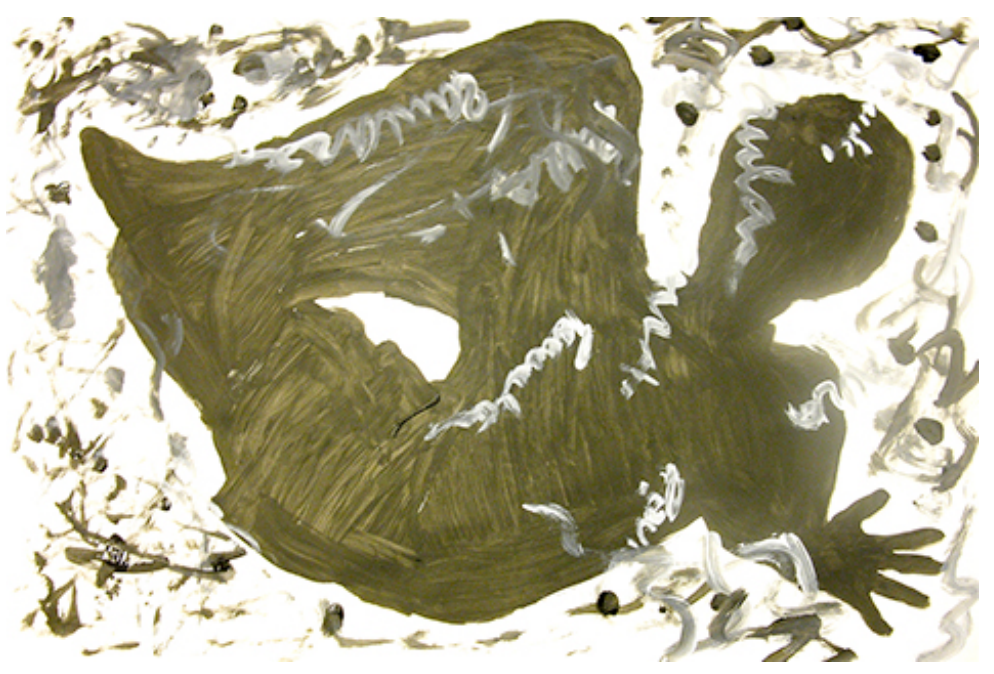

Trabalho de Sombra, Caligrafia e Gestualidade. Aula de Desenho de Observação. Anos 2000. Imagem de arquivo pessoal do professor. Fig. 2

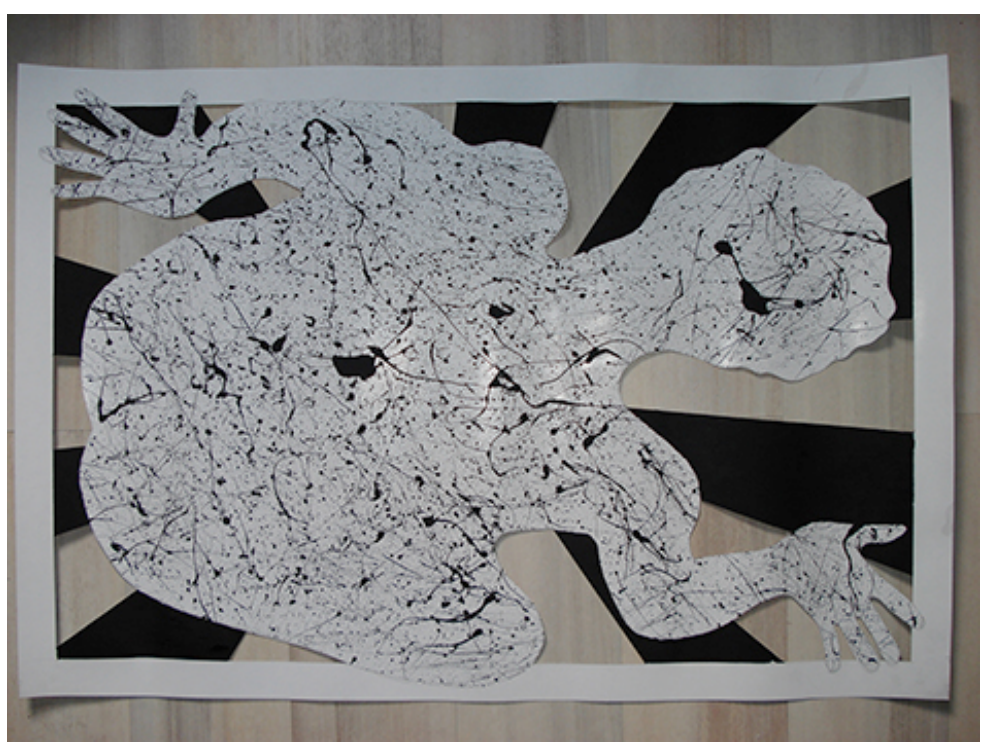

Trabalho de Sombra, Caligrafia e Gestualidade. Aula de Desenho de Observação. Anos 2000. Imagem de arquivo pessoal do professor. Fig. 3

Para começar a traçar um paralelo com as teorias e as didáticas da imagem pictórica que listei anteriormente, e assim manter a referência metodológica amplamente reconhecida, primeiramente, preciso ressaltar que o "traço", a que me refiro na pergunta central da atividade "Sombra, Caligrafia e Gestualidade", não é uma tentativa de definição de algum tipo de partícula visual formadora da imagem artística, mas a(s) marca(s) - qualquer mancha visível - criada, deixada ou gerada, na totalidade ou no(s) detalhe(s), em um processo técnico operado pelo estudante. 
Este primeiro passo na análise de uma imagem artística, conduzido em um exercício de desenho limitado às cores preta e branca, e suas naturais e acidentais variações em cinzas, indicava aos estudantes o tipo de "investigação" que deveria ser implementada quando se pretende entender a visualidade de uma obra bidimensional. Inclusive, conceitualmente, a palavra "investigação" sintetiza muito bem a metodologia em desenvolvimento.

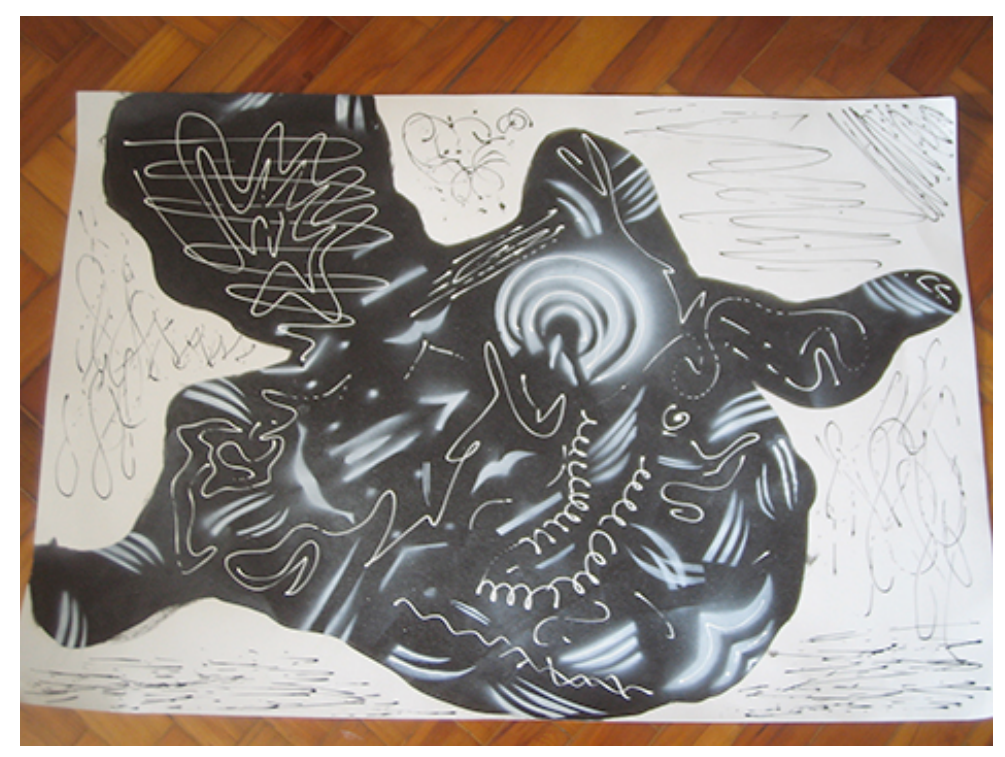

Trabalho de Sombra, Caligrafia e Gestualidade. Aula de Desenho de Observação. Anos 2000. Imagem de arquivo pessoal do professor. Fig. 4

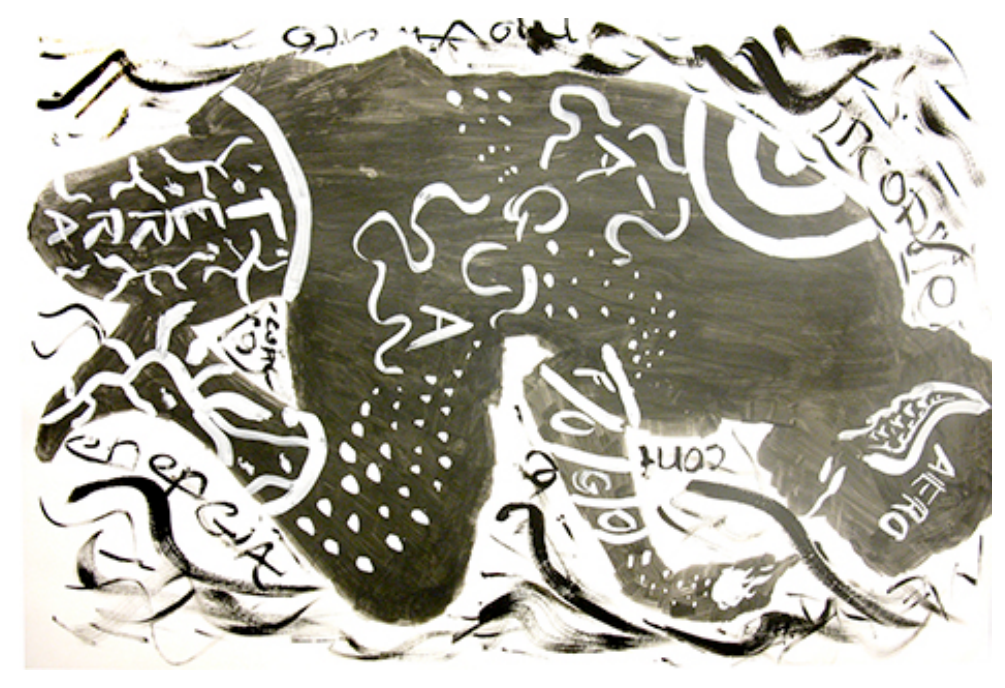

Trabalho de Sombra, Caligrafia e Gestualidade. Aula de Desenho de Observação. Anos 2000. Imagem de arquivo pessoal do professor. Fig. 5

Sempre que eu fazia a apresentação da atividade "Sombra, Caligrafia e Gestualidade", o discurso inicial era focado em exemplos sobre o caráter indiciático dos signos produzidos pela caligrafia dos estudantes. Seguindo com a 
reflexão, apontava para os signos resultantes dos seus gestos, ao aplicar com um pincel, com os dedos ou mesmo as mãos e braços, carregados de tinta preta sobre uma superfície branca, que registrava cada movimento do ato de pintar. Quando propunha rigores técnicos, aos estudantes, na hora de registrarem as próprias sombras, discorria sobre a forma humana idealizada pela imaginação e a simples reprodução mecânica do contorno projetado pela luz ou pelo carimbo da mesma. Nas análises que eu fazia sobre o processo da atividade em curso, com exemplos e associações sobre as qualidades indiciáticas dos traços produzidos, em uma sequência de poucas reflexões, era possível estabelecer conexões formais entre as mais variadas técnicas de desenho e reprodução, fotográfica ou relacionada. Apontando sentidos possíveis às imagens pintadas pelos estudantes, percorria-se a História da Arte desde as pinturas das cavernas paleolíticas, a tradição do perfil na arte do retrato desde a antiguidade clássica, os trabalhos dos primeiros modernistas, passando pelas experiências fotográficas de Muybridge e chegando até ao Expressionismo Abstrato, da Escola de Nova Iorque. Vale ressaltar o trecho do livro "O Ato Fotográfico e outros ensaios", no qual Philippe Dubois coloca na exata perspectiva o foco da atividade didática com o índice:

(...) será que a lógica indiciária, da qual a fotografia parece ter sido o modelo detonador, já não está presente e ativa sob formas variadas nas práticas representativas anteriores à existência do meio fotoquímico? Aqui também será mostrado que se deve responder positivamente e mesmo de maneira muito singular, pois se verá que, desde a origem, no primeiro momento fundador da representação (ou seja, sobretudo no(s) mito(s) da origem), a questão do índice, da conexão física singular do signo com seu referente, foi colocada e trabalhada ativamente. (Dubois, 1993, p. 112)

Muitos estudantes só conseguiam desenvolver todo o potencial da atividade com os traços indiciáticos depois de umas três apresentações e análises dos resultados. Ao propor uma atitude na interpretação de uma imagem artística, eu sempre sugeria a possibilidade de uma "investigação" da operação realizada pelo artista pelas qualidades das marcas ou manchas - a visualidade do traço -, onde o discurso da ideia expressa poderia encontrar uma narrativa na cultura. Eu colocava da seguinte maneira para os estudantes: "Quando um detetive entra na cena de um crime, ele procura por indícios, provas de contato físico do criminoso. Decifrando os indícios, ele refaz o caminho - o tempo, o movimento, o espaço -, 
do criminoso pela cena. E só depois, então, talvez, se à sua consciência interessar, poderá ele se perguntar: por quê?". Deixando claro que o porquê do "crime" não era importante, mas a compreensão do traço indiciático que conteria a ideia da visualidade da cena, sim. Mesmo sabendo que os meios técnicos podem variar, ainda assim, a ideia (a condução da operação) será única e a sua interpretação, imprevisível.

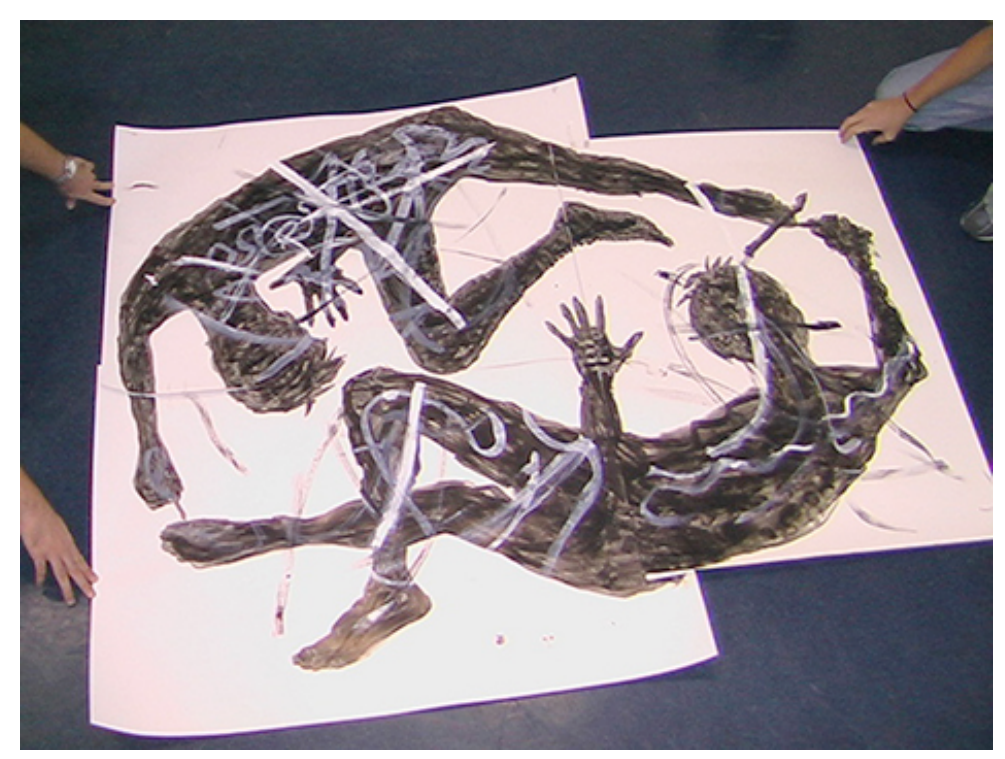

Trabalho de Sombra, Caligrafia e Gestualidade. Aula de Desenho de Observação. Anos 2000. Imagem de arquivo pessoal do professor. Fig. 6

A observação dos procedimentos técnicos, indelevelmente registrados no caráter indiciático da imagem observada, não tem o objetivo de atestar o processo criativo que a originou. Mas permitir ao estudante desenvolver uma consciência fundamental sobre aquilo que vê desfilar diante de si nos ambientes da internet e de seu meio cultural. Quanto maior for a intimidade com as qualidades visuais do índice, mais à vontade um iniciante ficará para começar a avaliar imagens artísticas. A questão estética envolvida neste ponto é fundamental para uma educação artística relevante. Destaco aqui outra colocação do livro "O Ato Fotográfico e outros ensaios":

A utilização, a esse respeito, da noção peirciana inscreve-se de fato num projeto global, do qual uma das linhas de fundo repousa na ideia de uma passagem da categoria de ícone à de índice, passagem considerada não apenas um marco histórico da modenidade, mas também, mais geralmente, como um deslocamento teórico, onde uma estética (clássica) da mimese, 
da analogia e da semelhança (a ordem da metáfora) cederia espaço a uma estética do traço, do contato, da contiguidade referencial (a ordem da metonímia). (Dubois, 1993, p. 113)

A dissecação conceitual da didática através da atividade "Sombra, Caligrafia e Gestualidade", logo de início, tem como objetivo introduzir a metodologia que servirá de guia para os outros elementos estruturantes da imagem artística. A questão do desenho da sombra, em seguida, envolve a análise de traço indiciático conectado ao pensamento original por trás de uma representação da figura humana. A reprodução da própria sombra, momento que provocava o maior fascínio dos estudantes com o trabalho, proporcionava a experiência raiz da mais difícil percepção de estrutura da forma: quando o traço tenta espelhar ou imitar as feições humanas. Fator biológico e psicológico inconteste, apontado por inúmeros estudiosos da imagem, e amplamente verificado em campo por mim, a percepção humana é inteiramente desenvolvida para reagir emocionalmente aos contornos de traços que evoquem feições, corpos humanos e suas partes. O problema na realização da tarefa de pintar a própria sombra estava na tendência, de todos, em harmonizar a imagem resultante projetada por diversos meios.

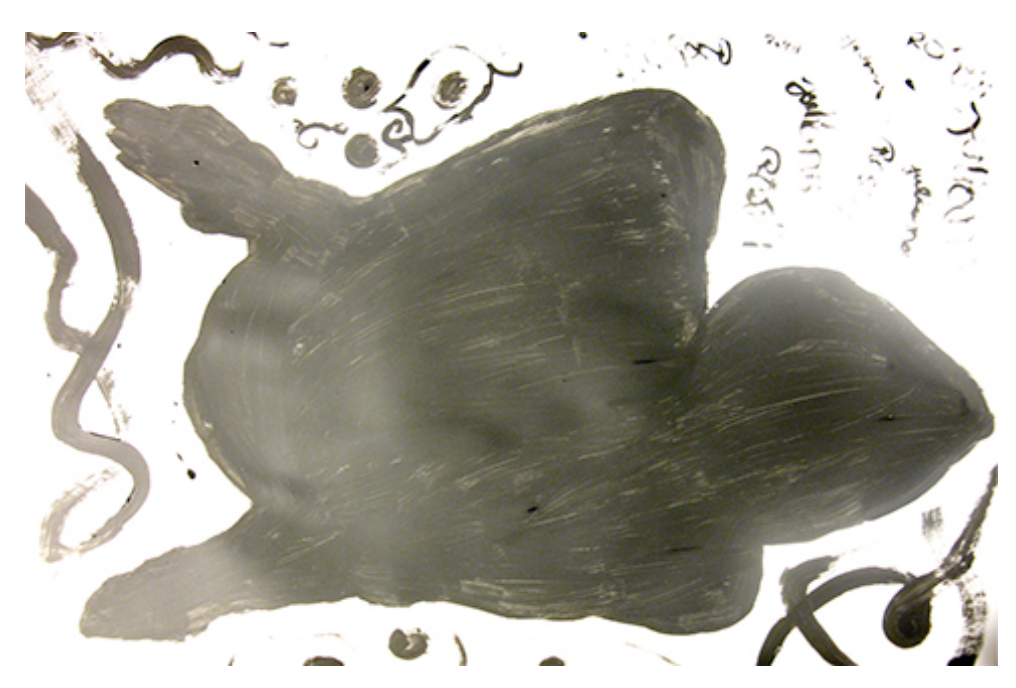

Trabalho de Sombra, Caligrafia e Gestualidade. Aula de Desenho de Observação. Anos 2000. Imagem de arquivo pessoal do professor. Fig. 7

Este momento da atividade, eu diria que era o de maior potencial didático para a compreensão do caráter do traço. Cada vez que um estudante embelezava o próprio perfil, idealizando os contornos, tinha início um debate a respeito da "sombra" criada. A sombra verdadeira deveria transparecer a mecânica pura da 
reprodução pela projeção de uma fonte de luz, caso contrário, o traço perderia a qualidade de índice de uma sombra para tornar-se ícone de uma figura humana. Porém, eu aceitava não apenas a sombra real produzida por uma fonte de luz para realizar o trabalho. Era possível, também, o uso de retroprojetores projetando reproduções fotográficas da imagem do estudante. Além disso, havia a possibilidade de operações do tipo carimbar o próprio corpo em partes no suporte branco, ou mesmo o registro direto do contorno do corpo com a ajuda de colegas.

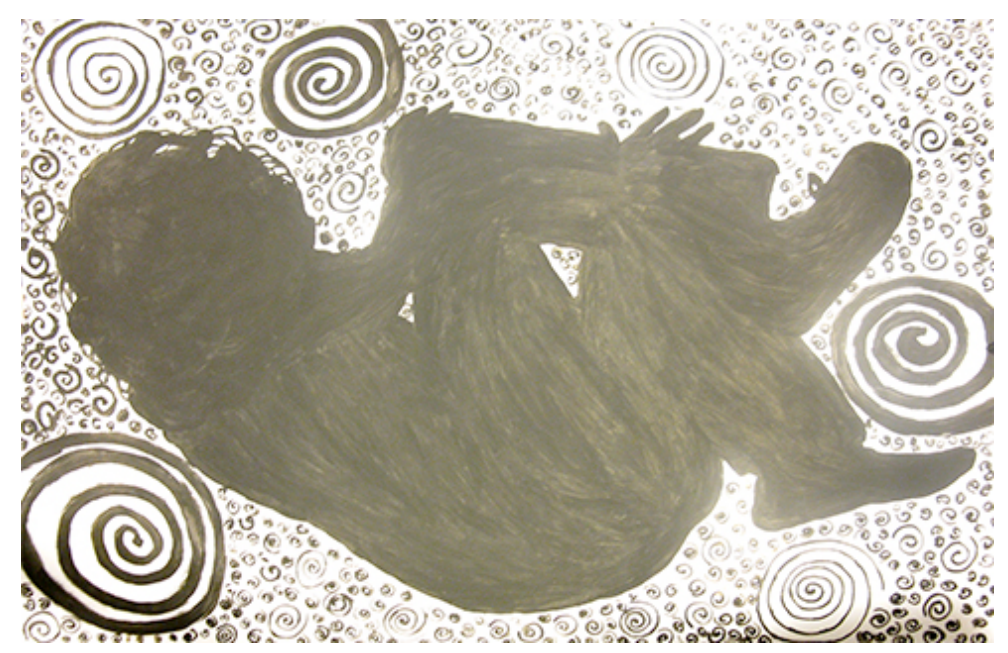

Trabalho de Sombra, Caligrafia e Gestualidade. Aula de Desenho de Observação. Anos 2000. Imagem de arquivo pessoal do professor. Fig. 8

Contudo, a grande descoberta dos estudantes, sobre como garantir que o traço não perdesse o caráter de índice de sombra, acontecia quando percebiam que a sombra distorcida podia perder totalmente a qualidade de ícone da figura humana, e se tornar apenas uma sombra. Ao reduzir-se a uma marca indiciática da mecânica da luz reproduzindo contornos de um corpo humano, corria-se o risco de outros significados serem agregados, mas também, muitas vezes, a sombra resultante era capaz de revelar com extrema nitidez a operação realizada pelo estudante. Nesse ponto, quando realizava as análises críticas dos trabalhos, era possível ir muito além da questão da mimese, da semelhança versus o contato, da ótica, na física da reprodução da figura humana. Era possível discutir com os estudantes sobre questões de representação de espaço sobre o plano pictórico. Após experimentarem na realidade diversas estratégias técnicas para fazer o registro de seus corpos, e de observarem os resultados, um mundo de processos criativos modernos e contemporâneos podiam ser revisitados com mais consciência sobre a estrutura da imagem artística. A este respeito, vale destacar 
este trecho do livro "O Ato Fotográfico e outros ensaios", onde Philippe Dubois cita Rosalind Krauss, falando sobre a fotografia e Marcel Duchamp:

Krauss enfatiza em particular Marcel Duchamp, por um lado, do qual mostra bem que quase toda obra, embora Duchamp jamais tenha praticado a fotografia de maneira direta, pode ser considerada como uma reflexão em torno da problemática do traço, do depósito, do contato, da proximidade, da inscrição referencial por intermédio de figuras sempre pragmáticas, como a moldagem, a sombra projetada, o transporte, o decalque, a transferência direta, o auto-retrato, o jogo de palavras, o readymade, etc. (Dubois, 1993, p. 113)

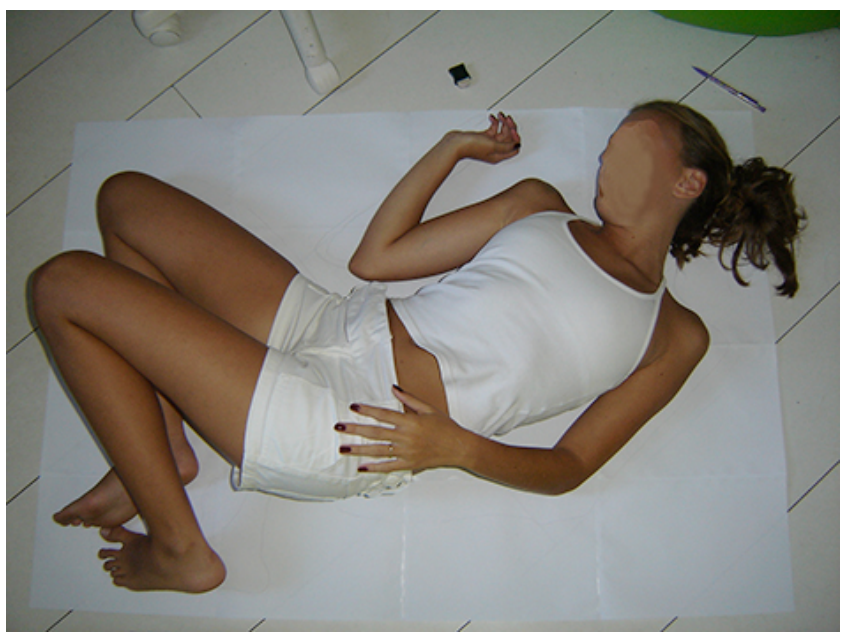

Estudante fazendo o trabalho de Sombra, Caligrafia e Gestualidade durante a aula de Desenho de Observação. Anos 2000. Imagem de arquivo pessoal do professor. Fig. 9

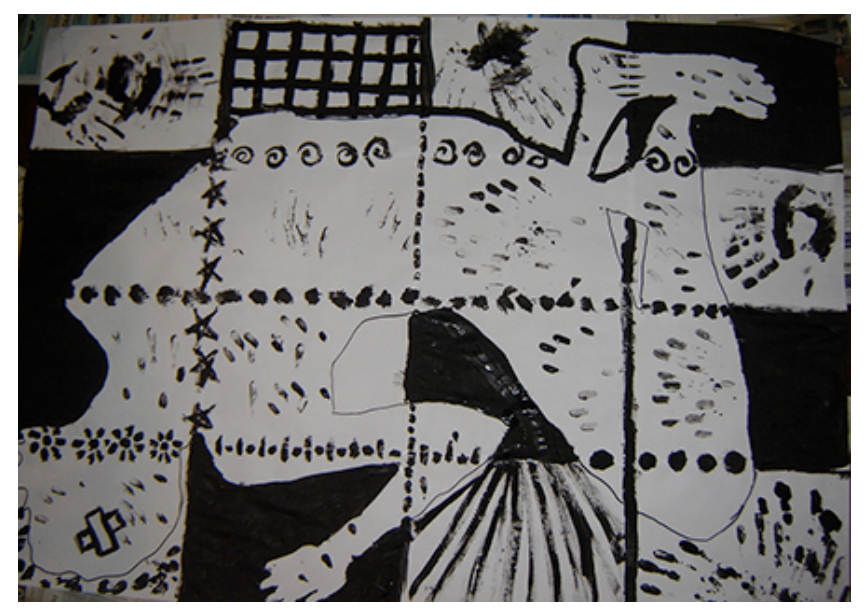

Trabalho de Sombra, Caligrafia e Gestualidade. Aula de Desenho de Observação. Anos 2000. Imagem de arquivo pessoal do professor. Fig. 10

Com esta citação, fecho o pensamento que me fez recuperar a didática das minhas aulas de Desenho de Observação, visando o ponto central deste projeto pedagógico, que é operacionalizar uma ação que ofereça aos estudantes de Artes e 
Design oportunidades de analisar criticamente o que veem na internet. Entre os problemas oriundos da falta de um repertório cultural significativo nos alunos ingressantes na faculdade, em cursos que trabalham com a imagem artística, a incompreensão da história da arte, da mecânica do traço, do signo e do seu sentido indiciático, da imagem técnica e de sua reprodutibilidade, a meu ver, são os mais prementes.

A grande possibilidade reveladora por detrás da compreensão do caráter do índice, fotográfico ou não, é a percepção da visualidade do pensamento artístico, atual e do passado, sem cair em armadilhas do senso comum ou da ilusão mercadológica imediatista. Mas o uso da fotografia, tão simplesmente, como uma fria fonte repetidora e modeladora digital, mantém sensibilidades reduzidas aos imaginários inflados dos hiperrealimos da lógica de consumo. O problema deste uso não seria por algum falso testemunho do real através da manipulação fotográfica, mas pela repetição contínua de um espaço virtual, não mais fotográfico no sentido tradicional, cujo único propósito é reduzir o foco dos ambientes e narrativas culturais aos valores de culto já negociados dentro do mercado.

Não é a minha intenção proceder de forma discricionária e ideológica ao tecer críticas sobre o universo visual do mercado de consumo, da forma como ele se apresenta na internet e no espaço público. O meu objetivo, essencialmente didático, é apontar aquilo que é mais raro, que demandou mais decisões criativas, que envolveu narrativas históricas mais complexas, que exige mais atenção e sensibilidade para a compreensão da ação artística. Em um sentido interdisciplinar, este projeto pedagógico poderia ser ampliado indefinidamente, e desenvolver até uma "História da Arte através de uma História do Traço" na internet, ou uma "História do Índice na Arte" através da internet. E não me refiro aqui a um estudo no sentido filosófico e semiótico daqueles realizados por Erwin Panofsky - quando relaciona Iconografia e Iconologia visando a compreensão de obras de arte, no livro "Significado nas Artes Visuais" (Perspectiva, 1991) -, mas a um estudo investigativo do traço, como signo indiciático, na iconografia presente na internet. Esta possibilidade torna-se especialmente viável nos dias atuais, quando vemos a empresa Google trabalhando para catalogar toda a 
informação visual disponível em museus, instituições, cidades e ambientes culturais do mundo inteiro. As imagens disponibilizadas pela internet são mais que suficientes para uma seleção historiográfica sobre a questão da representação figura humana, por exemplo. Esta constatação aponta para oportunidades valiosas quando imagino meios de transpor a didática artística pela origem do traço para ambientes educacionais. Ao recordar as dificuldades enfrentadas em sala, quando a internet era lenta, sem máquinas de buscas poderosas e conteúdo diversificado e detalhado, vejo quão pouco a exploramos atualmente em termos de educação artística, servindo apenas como biblioteca de imagens e museus virtuais.

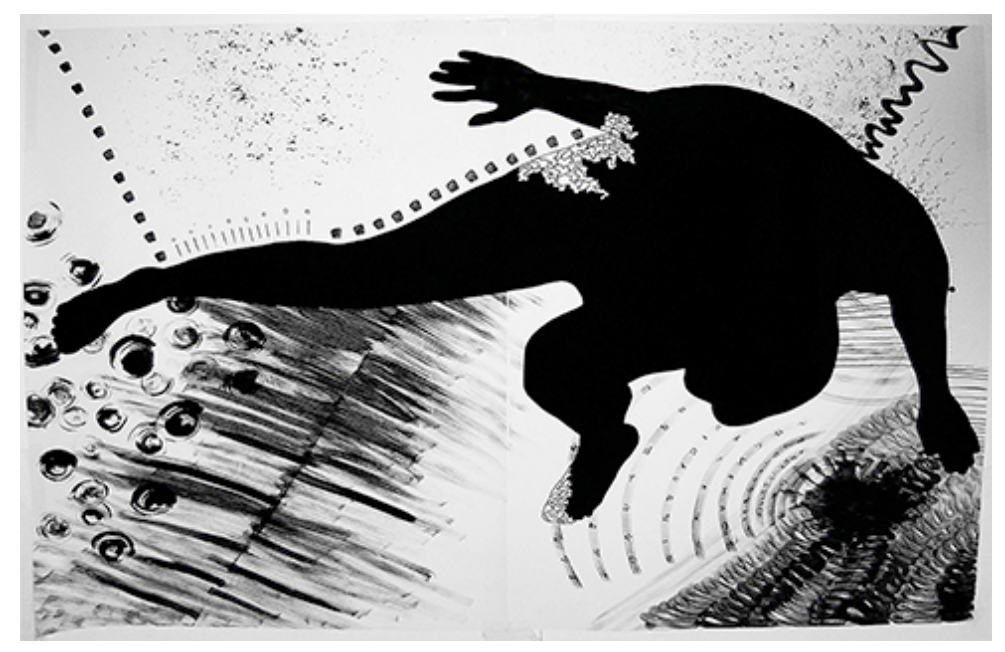

Trabalho de Sombra, Caligrafia e Gestualidade. Aula de Desenho de Observação. Anos 2000. Imagem de arquivo pessoal do professor. Fig. 11

\subsection{O traço e a representação de figura humana}

Retomando o desenvolvimento da compreensão da imagem artística e do desenho, à partir da questão da percepção da figura humana na atividade "Sombra, Caligrafia e Gestualidade", posso dizer que os estudantes, ao final do processo, estavam bastantes familiarizados com as operações técnicas e suas consequências para a identidade do traço. Porém, faltava-lhes a total dimensão das implicações conceituais do índice. Usando como suporte teórico a análise que Rosalind Krauss desenvolveu a respeito da escultura "As Três Sombras", de Rodin, no livro "Caminhos da Escultura Moderna" (1998), muitas estratégias de registros dos próprios corpos eram trabalhadas com os estudantes. Afinal, as possibilidades do signo indiciático incluir o registro de movimentos dos seus próprios corpos, assim como distorções e repetições mecânicas dos mesmos, agregavam muitos outros 
significados ao desenho da figura humana. A principal qualidade que buscava apontar, quando sugeria ideias aos estudantes, era a subversão da narrativa naturalista da forma através de decisões criativas puramente estéticas e experimentais. Citando a referida obra de Rodin, Rosalind Krauss descreve com precisão o recurso utilizado pelo artista em escultura - ao usar três cópias da mesma figura para compor a obra -, perfeitamente traduzível para a linguagem do desenho, que eu trabalhava em aula:

Contudo, a aparente simplicidade de Rodin dota suas figuras de um sentido de opacidade. As Sombras não criam entre si uma relação que pareça capaz de significação, de criar um signo transparente a seu significado. Em lugar disso, a repetição das Sombras redunda na criação de um signo totalmente autoreferente. (Krauss, 1998, p. 25)

O ponto mais importante, a meu ver, quando finalizava as orientações desta atividade, dizia respeito ao contorno das figuras produzidas pelos estudantes quando estes terminavam de pintar com tinta preta as suas próprias sombras. O nome da atividade era "Sombra, Caligrafia e Gestualidade", ou seja, o resultado final deveria ser uma combinação das visualidades dos signos resultantes destes três conceitos artísticos, sobre um plano pictórico branco com dimensões suficientes para caber o registro de uma sombra em tamanho real. Enfim, o valor descritivo dos contornos podia ganhar qualidades que se afastavam do seu referente, ou até mesmo ser o registro de uma ação de expressão que distorce este referente. Esta questão da figura humana na atividade era encerrada, então, com um discurso traçando um paralelo que situasse a experiência prática do trabalho com o traço indiciático, como uma introdução à compreensão essencial sobre a representação do nu moderno em relação ao nu clássico. A referência teórica utilizada para exemplificar esta distinção estava na comparação que Rosalind Krauss fez das esculturas "Je suis belle", de Rodin, com "Hércules e Anteu", de Pollaiuolo, no livro acima mencionado. Na primeira análise, ela declara a sua percepção da escultura de Rodin:

Existe ainda um outro nível em que Rodin desenvolveu esse veio quase perverso da opacidade: o modo como relacionava, ou deixava de relacionar, o aspecto externo do corpo à sua estrutura interna. Os gestos físicos produzidos pelas figuras de Rodin não parecem originar-se do que sabemos da subestrutura do esqueleto que suporta o movimento do corpo. (Krauss, 1998, p. 29) 
Sobre a escultura de Pollaiuolo, ela coloca:

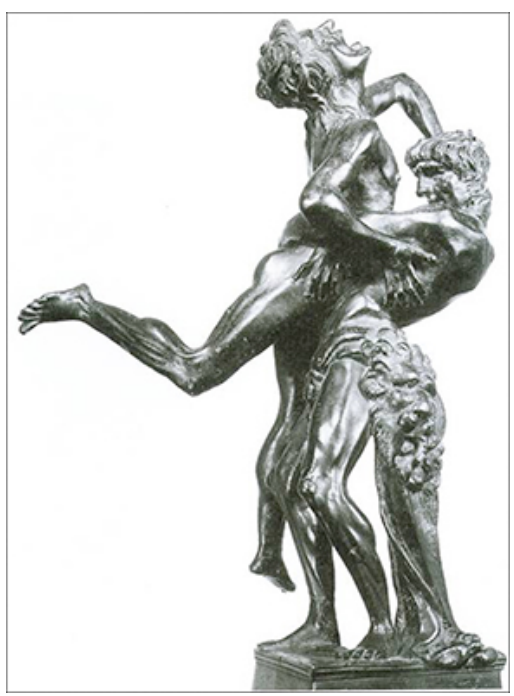

Antonio Pollaiuolo: Hércules e Anteu, c. 1475. Bronze, 45,7 cm. Museo Nazionale, Florença. Reprodução de imagem da internet. Fig. 12

O momento de luta mostrado por Pollaiuolo é plenamente explicado em termos do sistema de sustentação interna do corpo. A pressão do braço de Hércules cingindo e esmagando Anteu em um determinado ponto de sua coluna vertebral ocasiona uma reação que faz Anteu arquear-se e estirar-se; (Krauss, 1998, p. 29)

Sobre a escultura de Rodin, ela conclui:

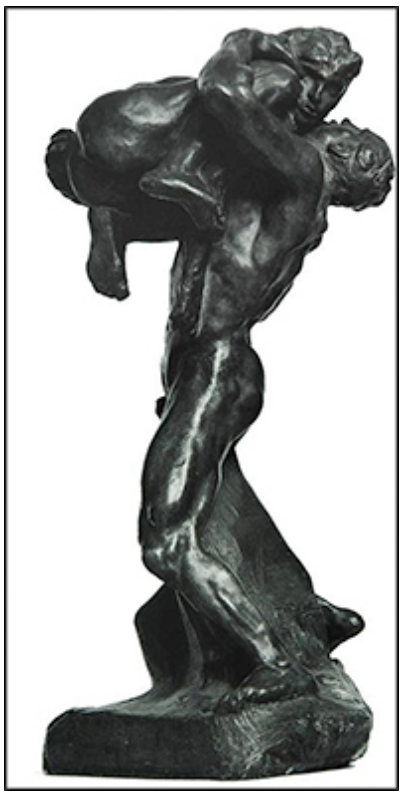

Rodin: Je suis belle, 1882. Bronze, $75 \mathrm{~cm}$ x $40 \mathrm{~cm}$ x 29,5 cm. Museu Rodin, Paris. Reprodução de imagem da internet. Fig. 13 
As costas arqueadas e os pés afastados da figura masculina indicam que ela está ao mesmo tempo caindo em razão do peso que carrega e erguendo-se para agarrar ou segurar a outra figura. Lido ao mesmo tempo como queda e expansão, o gesto contém uma ambivalência a qual o conhecimento que se tem da estrutura corporal não é capaz de apreender racionalmente. Analogamente, a figura feminina, recurvada e convertendo-se em uma bola de carne, projeta, ao mesmo tempo, uma sensação de peso e flutuação. É impossível penetrar como que no núcleo esquelético do corpo para descobrir o significado desses gestos. (Krauss, 1998, p. 31)

Parece estranho que um exemplo de crítica de arte sobre escultura possa servir a uma didática de desenho, sendo praticada tão somente com tinta sobre um papel cartão branco. Entretanto, no diálogo das formas, os referentes eram os corpos reais dos estudantes, cujos registros de suas sombras podiam definir contornos com as qualidades relacionadas à reflexão sobre esculturas feita por Krauss. Nesse ponto, vale ressaltar como a imagem fotográfica, em preto e branco, funciona no livro "Caminhos da Escultura Moderna". Quando este tipo de investigação da forma tridimensional têm como objetivo um livro com fotos, as escolhas de obras escultóricas tem que ser capazes de traduzir aquilo que a autora pretende. Não por acaso, Rosalind Krauss, logo na Introdução do livro, esclarece o porquê das escolhas de obras que fez em relação ao entendimento da forma que queria demonstrar. Este é um ponto importante para o meu projeto educacional, reafirmando que o achatamento fotográfico digital dos objetos culturais, dentro do universo da internet, não constituem de maneira nenhuma um fator de desinformação e ignorância. $\mathrm{Na}$ verdade, as limitações e os enquadramentos técnicos da cultura digital devem ser encaradas como fatores da linguagem contemporânea, que guardam informações potenciais a serem exploradas em um sentido educacional.

Não me parece razoável que o entendimento sobre obras visuais, que deveriam estar presentes nos fundamentos educacionais de estudantes, principalmente daqueles que se candidatam aos cursos de Artes e Design, possa continuar sendo negligenciado. Não se trata, aqui, de uma discussão sobre a pertinência das obras à cultura dos estudantes, mas da necessidade de uma formação mínima que envolva experiências estéticas absolutamente essenciais em um mundo de valores globalizados e intercambiados, entre culturas de diversos tempos. Fechando a questão da representação da figura humana e sobre como esta 
pode ser relacionada à uma prática estudantil, ainda envolvendo a atividade "Sombra, Caligrafia e Gestualidade", eu destaco a análise da leitura de perfil da escultura "Hércules e Licas", de Canova, por Krauss (1998), na comparação feita com as obras de Pollaiuolo e Rodin:

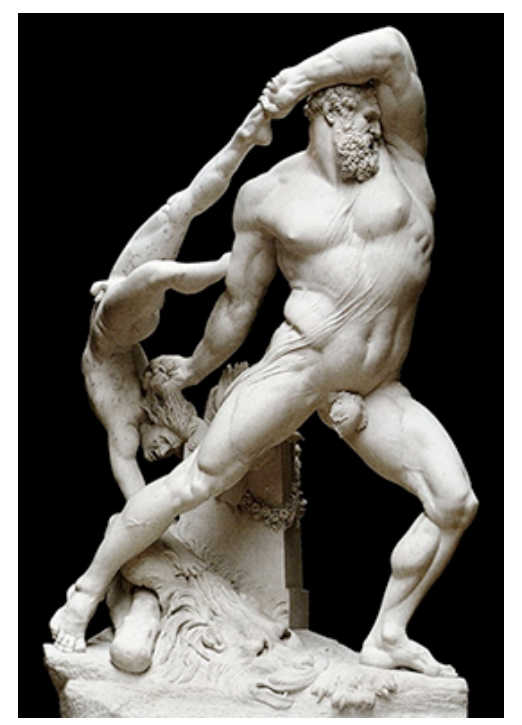

Canova: Hércules e Licas, 1812-15 (original, 1796). Mármore, 3,5 m. Galeria de Arte Moderna, Roma. Reprodução de imagem da internet. Fig. 14

(...) explora a relação entre dois corpos em luta dentro de um contorno único, definido mais radicalmente ainda e a partir de uma frontalidade ainda mais explícita. A satisfação que se tem ao considerar a obra de Canova é a que advém de uma sensação de definição - a sensação de que nossa visão particular da obra, quando a observamos de frente, permite-nos conhecer com absoluta segurança a mecânica do esforço que consome os dois corpos e que investe a ecultura de significado. (Krauss, 1998, p. 31)

\subsection{O traço, a representação de espaço e o plano pictórico}

Outro conceito que considero fundamental, relacionado à ação didática que pretendo formular, é o da representação ilusória de espaço sobre o plano pictórico. Reflexões relacionadas a esta conceituação eram muito importantes na investigação da qualidade do traço, dentro dos trabalhos executados para "Sombra, Caligrafia e Gestualidade". Porém, neste caso, a questão da codificação de espaço ilusório sobre o plano pictórico já havia sido discutida em uma atividade anterior e, assim, a abordagem do plano pictórico como recurso de ilusão de perspectiva ocorria de forma totalmente consciente. A atividade em 
questão se chamava "Fuga da Janela Renascentista" e, com certeza, era a proposta de exercício mais polêmica do meu programa de aula.

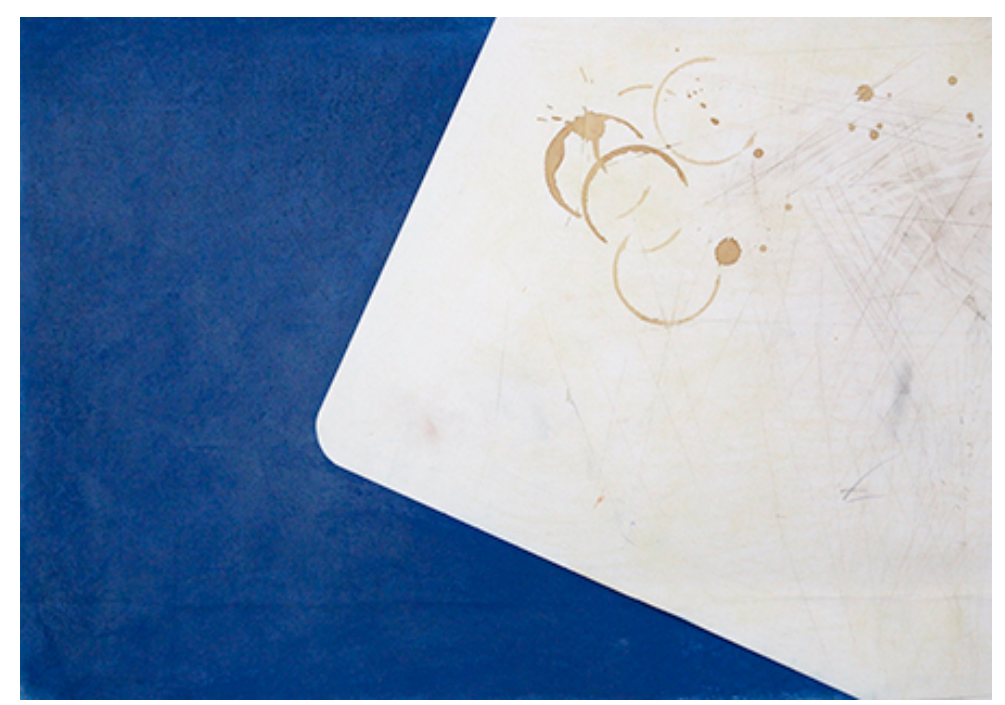

Trabalho de Fuga da Janela Renascentista. Aula de Desenho de Observação. Anos 2000. Imagem de arquivo pessoal do professor. Fig. 15

Idealizado nos meus primeiros anos como professor, o exercício "Fuga da Janela Renascentista” visava, justamente, organizar uma experiência prática com os estudantes que envolvesse um diálogo direto com a História da Arte. O motivo principal que me levou a criar este exercício foi a constatação da insuficiência de um repertório artístico mínimo em muitos estudantes. Esta deficiência geral de formação educacional ocasionava falhas na compreensão da proposta do exercício, assim como a falta de percepção das possibilidades criativas dos trabalhos que eram desenvolvidos ao final do curso. Porém, esta questão da padronização da percepção, formatação via códigos perspectivos incorporados nas molduras técnicas industrializadas e imagens midiáticas, era particularmente complicada de ser explicada.

A simples apresentação oral da proposta já era motivo de discussão sobre a validade da ideia a ser trabalhada. Observando a maneira como alguns estudantes usavam a folha de papel para representar espaço, eu identifiquei diversos condicionamentos psicológicos relativos aos códigos da cultura visual da sociedade. O objetivo era fazer os estudantes perceberem tais condicionamentos explicando a origem do formato da folha de papel, e apontando as percepções de verticalidade e horizontalidade como resultantes da representação renascentista de espaço. Era muito claro para mim, como professor, que os estudantes deveriam se 
perceber confinados em um espaço perspectivo mental, decorrente do imaginário culturalmente estruturado desde o nascimento. Essa consciência era fundamental para que pudessem entender o valor da "colagem" em uma obra cubista, por exemplo, em uma etapa seguinte. Após entenderem o plano pictórico da folha de papel, como um possível objeto estético pronto e não apenas como uma janela para a representação de ilusões - a famosa "janela renascentista" -, os estudantes poderiam experimentar uma atitude mais criativa quando chegasse o momento de trabalhar na atividade "Sombra, Caligrafia e Gestualidade".

A apresentação do exercício "Fuga da Janela Renascentista" começava com a análise de imagens da História da Arte, onde muitas questões sobre a percepção da realidade e a sua representação eram colocadas. Através de alguns exemplos simples sobre traços e manchas, ficava demonstrada a propensão do cérebro humano a interpretar ilusão de espaço onde não há sequer esta intenção. Usando como referência teórica o livro "A Perspectiva como Forma Simbólica", de Erwin Panofsky (1999), a construção do espaço perspectivo ganhava a sua devida dimensão filosófica para os estudantes, que só então começavam a avaliar os ganhos de conhecimento sobre a imagem artística que cada recurso pictórico oferecia. Percebendo a reverência geral dos estudantes pelo ordenamento matemático da perspectiva definida pelo Renascimento, dificilmente eu discorria além deste ponto para não sobrecarregar de conceitos a discussão em aula. Porém não deixava de demonstrar a subjetividade possível em arranjos de pontos de fuga e planos, nos trabalhos de artistas de períodos posteriores. O mais importante era que tivessem consciência sobre do que deveriam "fugir" quando riscassem sobre o plano do papel branco. Havia um trecho do citado livro que era sempre lembrado:

Nada mais poderemos fazer senão tentar imaginar o que terá significado esta realização na época. Não se limitou a elevar a Arte à condição de 'ciência' (o que representava uma subida de categoria no Renascimento). A impressão visual subjectiva foi sujeita a uma tal racionalização que essa mesma impressão acabou por se tornar o alicerce de um mundo de fundações sólidas, mas, ao mesmo tempo, num sentido completamente moderno da experiência, 'infinito'. Poder-se-ia até estabelecer uma comparação entre a função da perspectiva do Renascimento e a da Filosofia crítica, e a função da perspectiva grego-romana e a do Cepticismo. Resultou daqui ter sido o espaço psicofisiológico traduzido em espaço matemático. Deuse, por outras palavras, a objectivação do subjectivo. (Panofsky, 1999, p. 61) 
Acredito que nenhum conceito era mais difícil de ser explicado aos estudantes do que a subjetividade envolvida em representações de espaços perspectivos. Nesta categoria, havia ainda a da ilusão de realidade mediante recursos de reprodução técnica hiperrealista. Com o desenvolvimento da fotografia, uma vasta gama de discursos visuais baseados na reprodutibilidade da imagem documental fotorreal, assim como a reprodução em massa das imagens artísticas, vai agregar ao índice - traço indiciático do registro, hoje, ótico-digital, antigamente, ótico-químico -, a ideia de um recorte na realidade: o corte fotográfico. Além das muitas implicações e definições, o corte é explicado por Philippe Dubois (1993) como sendo essencialmente uma descontinuidade do espaço e do tempo, arbitrariamente representada no espaço de representação fotográfica - o ato fotográfico em si. O interesse do meu projeto pedagógico nesta questão se resume ao conceito de origem do traço, que desenvolvi no início.

Para minha didática, o importante é reconhecer o caráter indiciático do traço em uma imagem artística. Este aspecto é investigado na atividade "Sombra, Caligrafia e Gestualidade", quando os estudantes trabalham na reprodução da própria sombra através de fotografias. Concluindo a questão da ilusão de espaço em obras que visam enganar os olhos, eu ainda citaria as Trompe L'oeil, espalhadas em ambientes públicos e privados. A compreensão dessas imagens artísticas envolverá, como citei antes, a percepção do traço resultante da construção perspectiva, como índice fotográfico, e do corte, como espaço fotográfico, pelas características óticas presentes na imagem ou por outras superposições de valores, como o instante fotográfico. Logo, o fato da imagem artística não estar relacionada à descontinuidade do espaço fotográfico, isso não invalida a sua origem fotorrealista que, no meu entendimento, está presente em todo o imaginário da cultura atual. 


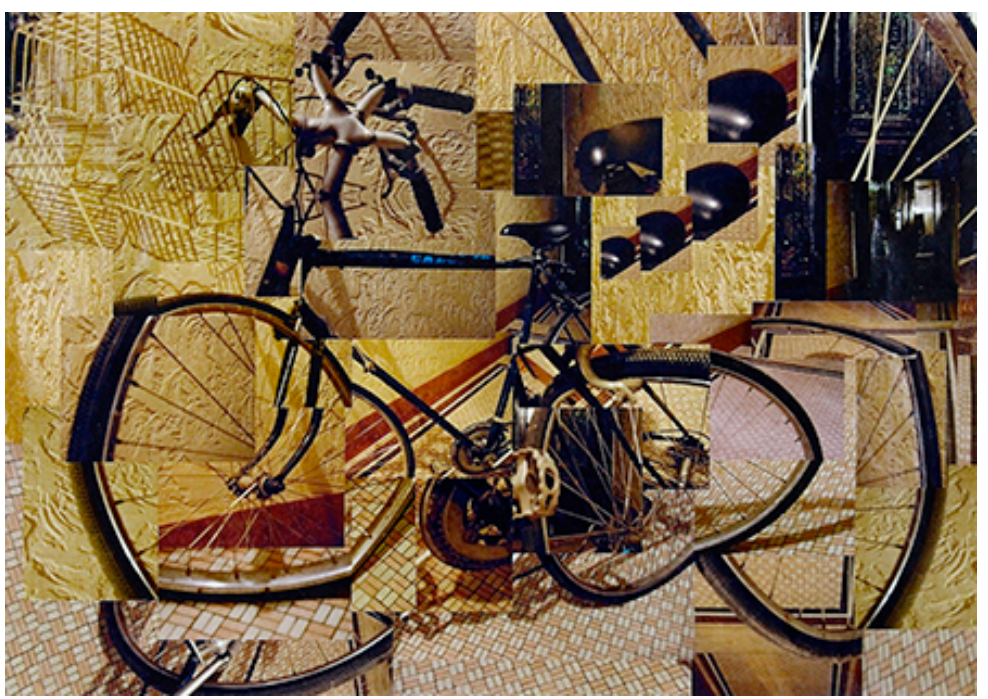

Trabalho de Fotocolagem. Aula de Desenho de Observação. Anos 2000. Imagem de arquivo pessoal do professor. Fig. 16

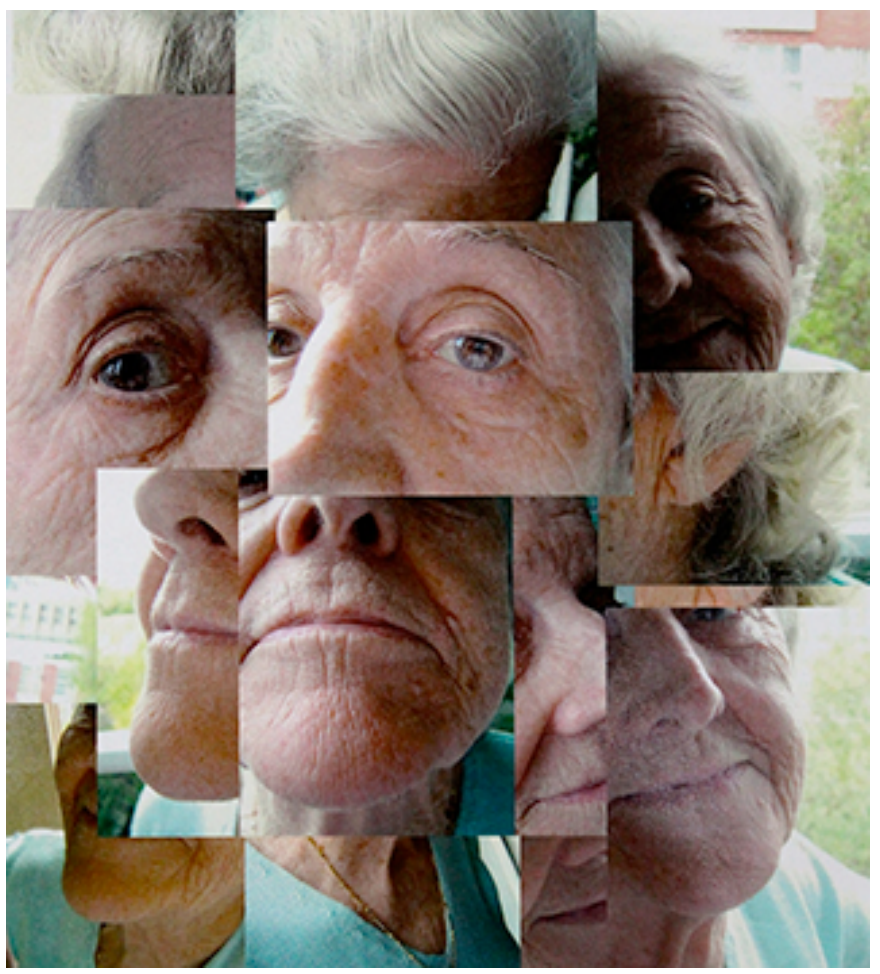

Trabalho de Fotocolagem. Aula de Desenho de Observação. Anos 2000. Imagem de arquivo pessoal do professor. Fig. 17

Na última questão de espaço abordada pela minha didática do traço, que se iniciava na atividade "Sombra, Caligrafia e Gestualidade", e terminava em um trabalho de desenho com fotos, chamado "Fotocolagem" - inspirado em David Hockney -, eu desenvolvia a questão da colagem cubista. Quando os estudantes trabalhavam seus grafismos e gestos na primeira atividade, com tinta preta sobre um grande cartão branco, as qualidades do traço sobre o espaço pictórico eram 
dadas pela narrativa experimental do Expressionismo Abstrato, Escola de Nova Iorque. E para atingir, com um mínimo de abrangência, o objetivo da minha disciplina, a estética cubista era investigada com fotocolagem. Um objeto tridimensional, fotografado em detalhes de todos os ângulos, deveria ter sua tridimensionalidade planificada com fotos sobre um suporte plano. Era mais uma estratégia para demonstrar conceitos fundamentais de ilusão e planaridade no uso do espaço pictórico. Nesta experiência prática envolvendo o princípio e o fim da arte do século $\mathrm{XX}$, eu apresentava a operação derradeira de ruptura criativa: a colagem. A intenção era proporcionar aos estudantes o contato na prática com os elementos estruturantes da imagem artística moderna e conteporânea. $\mathrm{O}$ fato do processo criativo cubista ter gerado, de forma embrionária, importantes trajetórias artísticas posteriores - como a de Marcel Duchamp -, e sempre envolver experimentações com as anteriores - como o rompimento da janela renascentista -, a atividade final para ilustrar esta proposta de ação didática necessariamente deveria passar pela colagem cubista. Esta situação emblemática, enfrentada por Picasso e Braque, está descrita por Clement Greenberg, no livro "Arte e Cultura" (1996):

Não há dúvida de que Braque e Picasso estavam preocupados, em seu cubismo, em se ater à pintura como uma arte de representação e ilusão. Mas de início eles estavam mais essencialmente preocupados, em seu cubismo e através dele, em obter resultados esculturais por meios estritamente nãoesulturais: ou seja, em descobrir para cada aspecto da visão tridimensional um equivalente explicitamente bidimensional, independentemente de quanto a verossimilhança sofreria neste processo. A pintura precisava proclamar - e não fingir negá-lo o fato físico de que ela era plana, ainda que ao mesmo tempo tivesse de superar esta planaridade proclamada como um fato estético e continuar a relatar a natureza. (Greenberg, 1996, p. 85)

Evidentemente, as operações virtuais possíveis para a construção de uma imagem artística utilizando a tecnologia digital são incontáveis. A minha intenção com este projeto de ação didática é desenvolver uma abordagem de compreensão da imagem artística e do desenho que utilize basicamente a internet. Diante da facilidade de acesso às imagens disponibilizadas pelas máquinas de buscas, me parece interessante que estratégias de leitura do traço fotográfico sejam 
desenvolvidas para estes ambientes. O cenário virtual, pela natureza da própria informação envolvida na sua codificação é, em essência, um cenário iconográfico. A leitura e a dissecação da imagem virtual requer, sem dúvida, um novo olhar. Além de seu potencial midiático e de sua reprodutibilidade infinita, agrega e mantém conceitos da fotográfica tradicional às suas possibilidades manipuláveis, o que dificulta a definição de muitos limites conceituais. Por outro lado, pela minha experiência, a flexibilidade do uso da imagem virtualizada ressalta os valores dos meios físicos. Gostaria apenas de apontar, com esta reflexão, que o mesmo caminho técnico que cria ilusões visuais contém o potencial para resgatar toda a realidade dos meios físicos originais.

\section{Propostas para um Ambiente Virtual de Aprendizagem}

Na minha visão, a melhor maneira de conduzir uma ação didática sobre compreensão de imagem artística, com foco em desenho e referenciada na História da Arte, seria através de um ambiente virtual principal que reunisse apresentações em várias plataformas virtuais distintas. A codificação tecnológica responsável e resultante dos atuais processos interativos sociais, fator essencial na construção e no uso de imagens em diversas narrativas públicas, precisa ser entendida como moldura e expressão cultural do imaginário atual. Para estruturar a didática fundamentada neste projeto, através da compreensão visual das possíveis origens do traço em imagens artísticas, primeiramente, será preciso que o problema da conceituação de traço seja colocado com exemplos técnicos e estéticos bastante claros.

Partindo da página principal, e inicial, do ambiente virtual de aprendizado, as palavras-chave, índice, ícone e símbolo, devidamente contextualizadas por outros termos e frases-chave, orientarão as buscas dos estudantes na internet. As orientações indicarão que essas buscas inevitavelmente precisarão ser relacionadas às imagens e vídeos dos conteúdos produzidos especialmente para a ação didática do projeto. Por exemplo: ao fazer uma busca por imagens com a palavra-chave "signo", ao lado de termos relacionados à arte tradicional, como "gestual" e "pintura", o estudante vai se deparar com um resultado muito diverso. Entre as imagens apresentadas pela máquina de busca virtual, estão aquelas do senso comum; mas estarão, também, algumas imagens cujo sentido visual é o que 
se pretende agregar ao universo cultural do estudante. Por meio de explicações ilustradas, previamente organizadas, sobre a origem do traço em questão - quando este é um signo, produzido gestualmente, sobre uma tela de pintura, por exemplo - a ação educacional começa, expandindo o significado de palavras e relacionando imagens. E uma segunda busca, desta vez apenas por imagens, revelará ao estudante o universo artístico com o qual poderá se tornar mais íntimo.

Paralelamente a esta tarefa, será aberto um fórum de debates. As obras audiovisuais ou imagens artísticas relacionadas às palavras-chave, selecionadas nas buscas, deverão ser postadas no fórum, juntamente com observações e comentários que demonstrem a validade do conceito de traço nas abordagens sobre as qualidades visuais das imagens. O objetivo da interação social, nesta primeira fase, seria uma preparação para as apresentações de conteúdos, com links complementares a serem pesquisados para cada aspecto visual compreendido. Depois, em três plataformas interativas distintas, apresentadas a seguir, as questões levantadas sobre o conceito de traço serão discutidas.

\subsection{Blogger - Blog para exposição de conteúdo - Conceituação de traço}

A abordagem feita em blogs permitem a exibição de vídeos e imagens em sequência de tópicos, favorecendo explicações e diálogos com links para materiais audiovisual e diferentes tipos de sites, que ofereçam informações sobre as origens mitológica e técnica da representação, por exemplo. Nesse início, os resultados das buscas dos estudantes poderão ser transformados em postagens por aqueles que orientam e administram o blog de aprendizagem. O diferencial que um blog oferece é a possibilidade de destaque para um assunto específico e o ambiente adequado para discuti-lo.

\subsection{Facebook - Página de Grupo Público - Discussão sobre traço}

A abordagem feita neste tipo de página do Facebook visa a exibição de vídeos e imagens em sequência, permitindo interações e diálogos mais ágeis, com vídeos e imagens sendo inseridas nos textos dos comentários. O principal objetivo, neste momento da ação didática, é permitir o contato aberto com o público e, assim, inserir possíveis novas narrativas culturais associadas aos traços analisados nas imagens artísticas. Novamente, a percepção do público sobre a 
imagem artística em discussão deverá conduzir as reflexões sobre a origem cultural do traço.

\subsection{Youtube - Canal de vídeos - Análise de trajetórias artísticas e históricas}

Nesta etapa da ação didática, depois das análises sobre as muitas imagens pesquisadas, a orientação para a busca passa a focalizar os processos artísticos e culturais. Vídeos sobre trajetórias artísticas específicas são indicados e discutidos. O Youtube oferece um longa lista de material audiovisual, permitindo a reunião e a comparação de vários registros técnicos e artísticos. Vídeos relacionados à temática de um determinado aspecto estudado poderá compor uma Playlist do projeto didático, visando as consultas futuras.

\subsection{Atividades}

Depois de realizadas as vivências visuais fundamentais, os estudantes agora serão desafiados a desenvolver a leitura do traço que cada imagem artística exige. Percebidos no detalhe e no todo da imagem artística, o traço, focalizado em quatro propostas de atividades sobre quatro maneiras de compreendê-lo, será dissecado em quatro ambientes virtuais distintos. Focando as origens das ideias cuja visualidade estruturou um padrão ou um conceito de traço, quatro narrativas culturais serão estudadas em relação a obras de arte específicas. Dessa forma, a ação didática passa a ser direcionada aos aspectos fundamentais e concretos da imagem, como descrito neste projeto pedagógico.

\subsubsection{Ambiente virtual I - Traço: matéria e signo do ato pictórico}

A primeira proposta de exercício seria uma investigação dos elementos visuais que fizeram parte da concepção visual da obra Les Demoiselles D'Avignon", de Picasso. Além da imagem carregar o caráter de algo inacabado e experimental, o resultado foi interpretado de início como um esforço fracassado e um "crime" contra o senso estético e o "bom gosto" pelos primeiros a contemplála. Essa ideia de "crime" se encaixa perfeitamente em um discurso didático através da origem iconográfica e indiciática do traço. Ao conduzir o estudante através dos objetos visuais e trajetórias artísticas, que supostamente construíram a 
vontade artística de Picasso naquele momento, este poderá entender as questões de representação e a relação desta com a imagem artística final.

Para falar de traço, como ícone de formas, índice de gestos, de caligrafias, e como resultado de "acidentes" na aplicação de tintas de cores diversas, a provocação inicial seria comparar a execução da obra de arte com um crime. Pode-se dizer, com alguma liberdade poética, que em algumas obras acontece um crime contra uma ordem de valores visuais e estéticos. O exercício começaria exibindo o "crime" praticado por Picasso através do "horror" daqueles que viram o quadro pela primeira vez. Uma obra audiovisual criada especialmente para esta implementação didática, no formato de um vídeo de 5 minutos com imagens colhidas na internet, o passo a passo dos acontecimentos seria reconstruído como em uma narração policial.

As cenas do audiovisual começariam exibindo as reações dos amigos de Picasso ao quadro, com narração em off e ilustrações no estilo de história em quadrinhos. Em seguida, a narração em off passaria a questionar a atitude "criminosa" de Picasso, indagando por onde ele teria "andado", que lugares ele teria "visitado", visualmente falando. Deste ponto em diante, os suspeitos de terem influenciado Picasso são listados visualmente: as pinturas de Gauguin; as formas de El Greco; as pinturas em vasos gregos; a escultura grega arcaica; as faces na escultura ibérica; a obra de Cézanne; a escultura africana. Porém, a culpa pelo "crime" poderá ser encontrada, também, em certas narrativas culturais e artísticas da época. Algumas temáticas pictóricas tradicionais serão analisadas rapidamente para tentar adivinhar uma motivação estética clara. Sabendo-se dos cuidados extras que Picasso teve com a tela, antes da execução, a narração em off finaliza sentenciando que a obra foi um "crime meticulosamente premeditado".

Evidentemente, muita coisa poderia ser pesquisada em relação ao cenário descrito na narração em off do audiovisual. Entretanto, quando o "crime" de Picasso em relação às figuras e ao plano pictórico - o fatiamento da figura e o achatamento da ilusão de espaço - é detalhado, os principais suspeitos de terem induzido a vontade do artista a riscar a tela daquela forma serão apontados. Aquelas obras e artistas acusados pelo estudante, de "colaboração cultural" na formação da famosa pintura, deverão ter os padrões de seus traços comparados. O 
estudante seria desafiado a agir como um investigador tentando desvendar os passos visuais de Picasso na execução do "crime". Frases no início, do tipo "o que teria levado Picasso a pintar aquelas formas daquele jeito?", seriam usadas para apontar as qualidades do traço da obra, e ao final, uma série de imagens de obras posteriores dariam a dimensão das consequências do tal "crime", como um marco visual do século XX. Esta seria uma primeira atividade que busca revelar a origem cultural de um traço pelos índícios visuais em uma obra, e pela análise de ícones e signos gestuais pictóricos de uma determinada ordem estética.

\subsubsection{Ambiente virtual II - Traço: anatomia e representação humana}

A segunda atividade proposta para a composição do AVA envolve a compreensão de imagens que reproduzem a figura humana. A página inicial do ambiente de aprendizado exibiria fotografias de modelos reais em comparação direta com as de diversas obras de pintura e escultura desde a antiguidade. O estudante teria a oportunidade de observar a transformação da representação anatômica através dos tempos. Acompanhando os textos deste estudo, haveriam links para tutoriais de desenho, pintura e escultura da figura humana já existentes na internet.

A ação didática no ambiente virtual desta atividade acontece quando vídeos adicionais, explicando os procedimentos práticos dos tutoriais, em relação aos resultados pretendidos, demonstram a estreita correspondência das formas anatômicas reais com aquelas representadas nas obras finalizadas. Este ponto é muito importante para apontar a simples reprodução mecânica da realidade, quando o traço indiciático da fotografia está presente em uma imagem, e em que momento surgem decisões criativas no processo de representação, que interpretam o real. Existem muitas dúvidas quanto à arte hiperrealista, sobre a sua origem fotográfica, ou quando ela supera a fotografia. Este aspecto poderá ser explicado na análise prática e na observação do traço, na busca das possíveis decisões criativas do artista.

O objetivo principal desta atividade é demonstrar que, tanto no detalhe mínimo quanto na imagem inteira da figura humana representada, podemos encontrar formas e proporções indicativas da sua origem naturalista ou 
fotográfica. Quando pesquisamos os padrões visuais das formas humanas, podemos conjecturar sobre a origem do traço expresso por um artista e sua cultura, assim como deduzir a estrutura fotográfica da imagem. As culturas artísticas da antiguidade clássica, cujas visualidades não foram expostas à codificação realizada pela reprodução mecânica da realidade, cultivavam estratégias técnicas e criativas para fazer uma reprodução do corpo humano que suas percepções de realidade julgavam ser o real. Essas estratégias podem muito bem ser reconhecidas como sendo uma linguagem plástica da época. Saber identificar o traço do presente e do distante passado, no modelado de uma anatomia humana, é fundamental para o estudante desenvolver uma percepção estética diferenciada.

Fechando a atividade, textos e vídeos sobre os mitos de Dibutades e Pigmaleão*, situando-os dentro do contexto da cultura digital, são apresentados. Dibutades é o mito fundador da pintura que, curiosamente, a une com a fotografia. Pigmaleão, no sentido escultórico, pode ser entendido como o mito do ser humano sintético, hiperreal e perfeito, fabricado pela tecnologia. Em ambos os casos, temos o traço de uma "beleza iconográfica" perfeita, cuja operação geradora foi por motivo, ou motivadora, de uma imensa paixão. Contudo, o sentido de permanência, presença, pela reprodução perfeita da forma humana, é a vontade artística original, mitológica. Em seguida, textos e vídeos com diversas imagens artísticas de robôs humanóides, de filmes de ficção científica, e personagens das realidades virtuais de jogos, seriam selecionados; fechando com a história da obra "A pequena bailarina de catorze anos", de Edgar Degas, cujo foco na problemática social em que a peça foi concebida e apresentada oferece uma outra dimensão emocional à ideia de perfeição física. A narrativa em off, dos contextos das imagens artísticas, situa para os estudantes os contrastes culturais que emolduram o mesmo desejo humano de permanência.

O final desta atividade seria um questionamento a respeito da representação de figura humana que mais profundamente permanece na memória do estudante e por quê, com perguntas desequilibradoras de concepções do senso comum, tais como: "O que poderia ser, afinal, um traço da perfeição na 
representação da forma humana? Existe mesmo essa ideia de perfeição? Em que circunstâncias?"

*Os mitos citados: Dibutades é o nome atribuído a Butades, um dos primeiros modeladores em argila da Grécia. Sua filha, Kora, teria se apaixonado por um jovem e riscou o contorno da sombra de seu perfil em uma parede. Butades teria modelado um rosto à partir do contorno. A origem do desenho e da pintura é creditado a este processo. Pigmaleão foi um rei grego, também escultor, que esculpiu a estátua da mulher que julgava perfeita em todos os sentidos, e se apaixonou por ela. A deusa Afrodite tranformou esta estátua em uma mulher real e ele se casou com ela. Pigmaleão é um mito que fala das expectativas em relação à realidade, também associado à realidade virtual como um meio de representação da perfeição humana.

\subsubsection{Ambiente virtual III - Traço: ilusão e codificação espacial}

A atividade seria uma investigação sobre os elementos plásticos que formam a ilusão pictórica de espaço, e como essa estrutura representacional expressa uma narrativa, uma visão de mundo, uma percepção de tempo. O ponto de partida seria um vídeo, uma obra audiovisual criada especialmente para este fim, reunindo diversas imagens colhidas na internet, desde a perspectiva gregoromana, passando pelo Renascimento, com trechos mais explicativos sobre a visualidade de obras fundamentais como "A Última Ceia", de Leonardo Da Vinci, chegando ao século XIX, quando o corte fotográfico apresenta a descontinuidade espacial, e o instantâneo como o ato fotográfico de fragmentação do tempo e sequência temporal, resumindo, então, a experiência visual fundadora da imagem técnica do século XX.

Paralelamente, uma wiki seria proposta, tendo como base uma sequência de imagens de obras modernas e contemporâneas, que seriam objeto de discussão, em textos de autores de referência e em comentários escritos pelo professor. $\mathrm{Na}$ sequência de imagens, começando com "O Grito", de Edvard Munch até as pinturas de Anselm Kiefer, chegando ao cartoon, a representação de espaço é apresentada como um recurso de infinitas possibilidades narrativas. Adicionalmente, com a indicação de uma série de buscas no Google, à partir de imagens fotográficas da atualidade, assim como do traço produzido em obras de origens diversas, teria início uma investigação da imagem artística e do desenho para entender a visão artística em termos de espaço que se expressa nos dias atuais. 
Um fórum final de discussão sobre a narrativa em imagens artísticas é aberto, e diversas fotos são aleatoriamente selecionadas na internet para que os estudantes falem sobre os códigos visuais que são capazes de identificar. O traço, como índice e como corte fotográfico, percebidos na concepção de espaço, são interpretados em suas qualidades gerais e as últimas conclusões são apresentadas.

Ao final, os estudantes serão convidados a usar recursos digitais em fotos para alterar as suas estruturas visuais originais e se expressar em imagens que envolvam qualquer tipo de representação de espaço.

\subsubsection{Ambiente virtual IV - Traço: conceito cultural e artístico}

Nesta última atividade, o objetivo é re-contextualizar a questão conceitual da arte, do início do século XX para o início do século XXI, e propor esta reflexão aos estudantes à partir da percepção e compreensão da origem do traço. Um texto no início da página apresenta a situação: Em 1911, houve uma apresentação teatral que encenava "Impressões da África", de Raymond Roussel, uma bizarra descrição da literatura francesa sobre a festa de coroamento de um rei africano, em uma nação tribal próxima derrotada por ele. A festa foi organizada por náufragos franceses, compostas de artistas de circo e cientistas. Cada um deles produziu um espetáculo próprio, sem nenhuma relação narrativa entre eles. Entretanto, entre cada ato, há um elemento temático que cria uma relação entre os espetáculos sobre o festejo do rei africano: uma série de máquinas primitivas que, dispondo de intrincados mecanismos, produzem um mesmo produto: “arte”. Eram várias as máquinas, de vários tipos de arte. Havia entre elas a máquina de pintura, por exemplo. Uma chapa fotossensível fixada em uma roda com vários pincéis, que girava quando imagens de paisagens incidiam na chapa. A transmissão do registro da imagem impulsionava os pincéis que a reproduzia em óleo sobre tela.

Sobre este espetáculo, no livro "Caminhos da Escultura Moderna", onde me apoio para fazer a sucinta descrição acima, Rosalind Krauss deu a sua interpretação das cenas assistidas por Marcel Duchamp e por outros importantes integrantes da vangarda de Paris:

O espaço literário das Impressões é habitado, portanto, por um grupo de pessoas que mecanizaram a rotina da criação artística. 
As forças biológicas e físicas de que elas se utilizam transformam-se em máquinas que criam imagens - imagens que reconhecemos como a base da experiência por nós identificada como arte. Ao automatizarem a produção artística, no entanto, as máquinas chegam a um resultado no qual a estrutura da imagem está absolutamente desvinculada da estrutura psicológica e emocional do indivíduo que dá início à arte, que põe a máquina em funcionamento. (Krauss, 1998, p. 86)

Em seguida, Krauss narra o início da fase madura da arte de Marcel Duchamp, quando este se afasta definitivamente do cubismo, um ano depois, passa a pintar máquinas e, por volta de 1913 e 14, a se apropriar de objetos industriais. Para assinalar a questão central desta fase do "ready-made", Rosalind Krauss destaca que sua obsessão podia ser sintetizada em uma pergunta: "o que ‘faz' uma obra de arte?’.

Assim como em Dibutade, o mito fundador da pintura que estabelece uma origem comum com a fotografia, a máquina de pintura da apresentação "Impressões da África" refaz a mesma ligação e vai além: na máquina de pintura quem pinta é a máquina. Rosalind Krauss afirma que há uma desvinculação da estrutura da imagem com a estrutura psicológica e emocional do indivíduo que dá início à arte, que acionou a máquina. Será mesmo?

Os produtores e cenógrafos da apresentação "Impressões da África", assim como Marcel Duchamp, que assistiu o espetáculo, e Rosalind Krauss, que escreveu sobre a percepção de Duchamp sobre a estética do espetáculo, no livro "Caminhos da Escultura Moderna", não conheciam o que existe hoje em termos de "máquinas de fazer arte". O traço produzido pelas máquinas digitais é um efeito visual resultante de muitas operações tecnológicas projetadas e acionadas por mentes humanas. Logo, é razoável concluir que o traço digital possua uma qualidade humana. Existem deslocamentos na atual percepção de arte produzida por humanos e por máquinas. Eis a questão central em dois passos para o estudante refletir e desenvolver:

1) Uma imagem artística é a expressão de uma cultura. Escolha imagens (fotos e desenhos) do seu universo pessoal, que expressem sentimentos e identidades. 
Explique as narrativas culturais e as operações técnicas que desencadeou para que as suas escolhas fossem concretizadas e os desenhos produzidos.

2) Desenvolva o fluxograma de uma "máquina" que imagine ser capaz de reproduzir os caminhos da sua criatividade e habilidades, e produzir imagens com as qualidades e características que julgue adequadas ao seu senso estético e gosto pessoal. Aponte quando o traço é mais humano e quando o traço é mais artificial.

\section{Mapa Conceitual da Ação Didática}

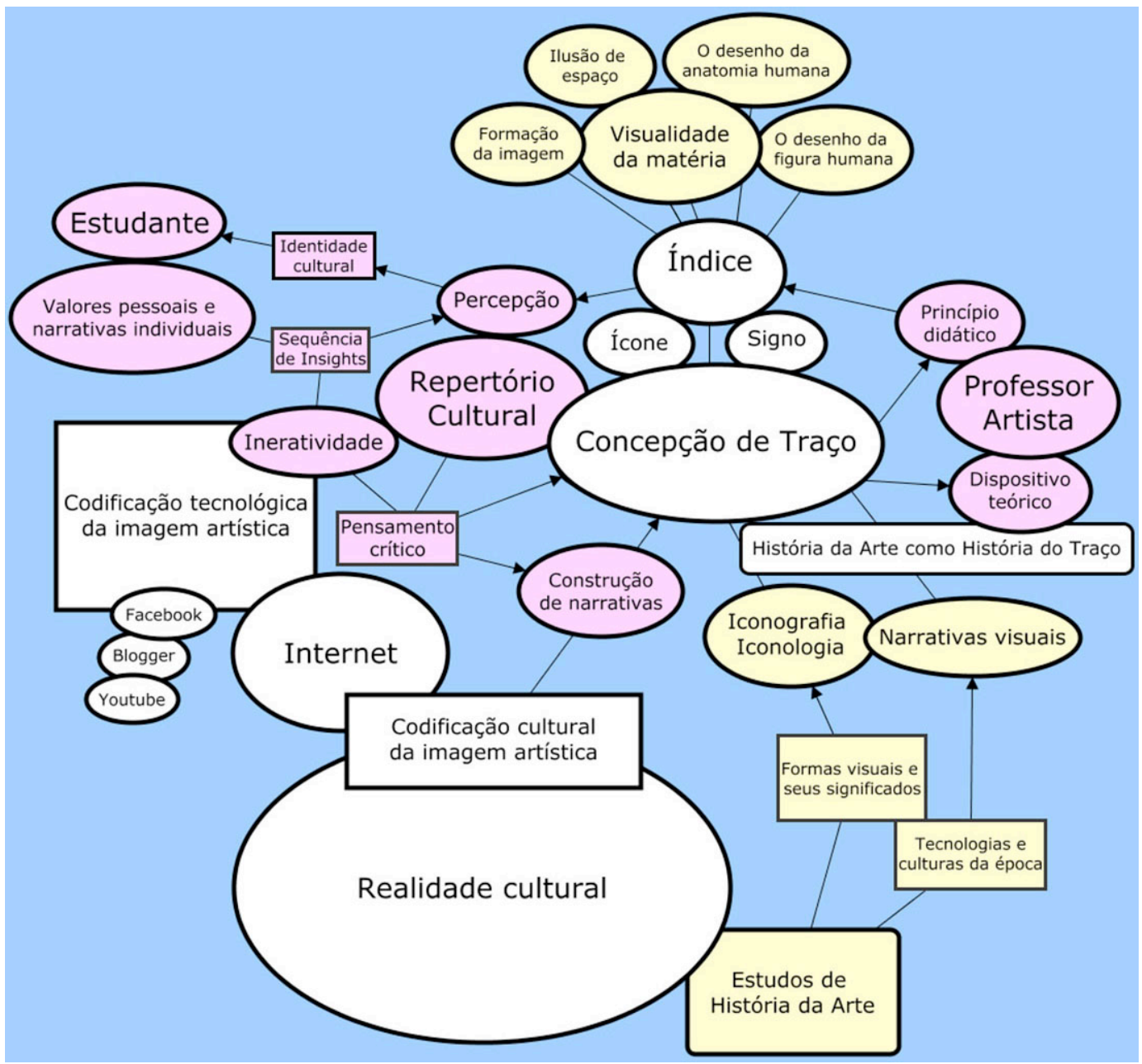

Mapa Conceitual**. Cor rosa: ação didática. Cor amarela: conceitos e textos acadêmicos. Cor branca: conceitos visuais e processos tecnológicos em transformação e elaboração. Fig. 18.

Neste Mapa Conceitual estão relacionadas as ideias abordadas no projeto pedagógico e os contextos culturais onde a ação didática será desenvolvida. A intervenção educadora é visualizada através da elaboração de um conceito central, 
o de "traço", capaz de incorporar permanentemente a transformação tecnológica da sociedade e as suas narrativas visuais.

**Retângulos com ângulos retos em cor branca: as duas mais importantes codificações de imagens. Suas relações com a Realidade Cultural, na grande oval branca, resultam nos conceitos e ideias assinaladas nos retângulos com ângulos retos em cor amarela. Retângulos com ângulos retos em cor rosa: conceitos trabalhados na ação didática. Retângulos com ângulos arredondados: dois desdobramentos das duas importantes codificações de imagens. Ovais: conceitos, ideias e agentes em construção permanente, cuja definição e atuação depende do contexto e da abordagem pedagógica.

\section{Conclusão}

Todo semestre, quando apresento aos estudantes alguns conceitos e referências básicas da História da Arte, nas minhas aulas expositivas, começa o drama de ter de parar a fala introdutória da atividade em foco para explicar uma simples palavra ou expressão. Paralelamente, nos últimos 3 ou 4 anos, a adoção de smartphones pelos estudantes e a sociedade, como um dispositivo de comunicação em tempo integral, tornou-se uma realidade. Novos hábitos culturais, disseminados por esta mudança tecnológica nas relações e práticas sociais da vida urbana, foram introduzidos em sala de aula. Os costumes e as rotinas pessoais dos estudantes mudaram, mas nem tudo relacionado a esta mudança pode ser considerado positivo. Dependendo da situação didática em questão, surgiram avanços e retrocessos na compreensão da imagem artística, do desenho e da cultura relacionada. Entretanto, não há como negar que o acesso à internet pelos dispositivos móveis de comunicação é uma poderosa ferramenta disponibilizada para qualquer disciplina. Pois é justamente através deste novo cenário tecnológico da sociedade que venho descobrindo e desenvolvendo formas de sanar as deficiências de compreensão de imagens artísticas que verifico nos estudantes.

Sempre é constrangedor falar sobre questões envolvendo a "representação de espaço no plano pictórico", por exemplo, e verificar que a maioria dos estudantes não faz a menor ideia do que sejam essas questões. A atividade cuja didática foi usada para desenvolver este projeto pedagógico, "Sombra, Caligrafia e Gestualidade" - criado especificamente para envolver vários fundamentos de arte e desenho em uma única atividade -, demonstrou em sua prática, através dos anos, que poderia haver na sua abordagem uma metodologia de compreensão da 
imagem. Fundamentado teoricamente na tricotomia peirciana (Charles Sandres Pierce, filósofo e semiótico americano, 1839-1914), “ícone, índice, símbolo”, e nos conceitos visuais operacionalizados na produção de imagem pictórica e fotográfica, os desdobramentos desta atividade construíram uma compreensão de traço que poderia servir como princípio interpretativo de imagens. Quando entendemos o traço como um efeito visual formativo da imagem e efeito visual da imagem em sua totalidade, ao mesmo tempo, fica claro o potencial didático desta conceituação. A análise do traço como índice, indicativo de contato físico com o referente, ou resultante de alguma técnica, ou um ato expressivo e comutador de elementos culturais, revela as narrativas criativas sobre as quais é possível a construção de discursos estéticos. Na qualidade de ícone ou símbolo, o conceito de traço é ampliado e incorpora conhecidas metodologias de compreensão da imagem artística e sua aplicabilidade educacional, como na semiótica.

As outras duas atividades usadas, "Fuga da Janela Renascentista" e "Fotocolagem", também foram criadas juntas com "Sombra, Caligrafia e Gestualidade" visando oferecer vivências artísticas básicas aos estudantes. O primeiro, explicava os códigos culturais expressos em espaços perspectivos; o segundo, experimentava com a técnica e o traço fotográfico. O intuito deste último era conduzir os estudantes em investigações cubistas do real, mas a prática revelou-se muito eficiente para esclarecer as tais questões de "representação de espaço no plano pictórico". Quando constatamos, hoje, a onipresença que a visualidade fotográfica atingiu com o desenvolvimento da tecnologia digital, parece-me indiscutível que uma realidade traduzida em fluxo imagético é construída diariamente no espaço virtual da internet. Pensando nessa forma de vivência cultural do indivíduo na sociedade atual e relacionando-a com a minha experiência como professor, verifico que os desdobramentos tecnológicos e estéticos do uso da imagem artística em plataformas interativas são compulsoriamente didáticos. A percepção e o imaginário, individual e coletivo, nunca estiveram tão intimamente e velozmente relacionados à seleção e produção de imagens em geral, e as artísticas em particular.

Diante deste nivelamento digital de todas as aparências e visualidades das culturas atuais e passadas, resultando em um "achatamento" cognitivo que 
formata a apresentação do mundo para os indivíduos, parece-me obrigatório pensarmos sobre como a História da Arte é percebida e traduzida na cultura digital. Partindo do princípio que esta reprodução fotográfica da realidade está sendo disponibiliza dentro de uma moldura tecnológica similar em todo o mundo, caberia refletir sobre uma metodologia derivada da atual prática fotográfica para se contextualizar as imagens e estudá-las. Krauss (op.cit.), ao situar o início conceitual do trabalho de Marcel Duchamp, fala da mudança de sua temática que havia se tornado mecanicista, até chegar o ponto em que o trabalho manual se transformou em um ato de selecionar. E resumiu a obsessão de Marcel Duchamp em uma pergunta: “o que 'faz' uma obra de arte?” (p. 88). Curiosamente, Philippe Dubois (op.cit.), aborda a relação entre a arte de Duchamp e a fotografia para elaborar aquilo que chamou de "lógica indiciária", e cita a própria Rosalind Krauss. O valor desta sua citação para o presente projeto pedagógico é o fato de apontar para convergência do processo fotográfico e pictórico, no qual a obra é apenas uma parte, uma possibilidade de síntese, um traço (p. 257).

O fato incontestável, e verificável na trajetória da arte européia entre os séculos XIX e XX, é que a visualidade de uma sociedade ilustra, cria e reflete o imaginário de seus indivíduos. A noção de pertencimento que as comunidades da internet buscam nutrir são extremamente visuais. Praticamente, não há texto sem uma imagem, porque a moldura e a prática virtual sempre a exige. A complexidade da situação que descrevo está na mecanicidade do pensamento que se revela através da imagem artística. O universo fotográfico que envolve a atualidade não está mais restrito à materialidade dos conceitos elaborados por Philippe Dubois (op.cit.). A imagem fotográfica, ao mesmo tempo que perdeu o caráter de índice de um real, de corte, de descontinuidade do espaço real, ganhou a dimensão autoexplicativa dos metadados e a possibilidade de manipulação infinita. Mas se, por um lado, toda imagem digital é manipulável, por outro, os dados desta operação - a assinatura digital - são recuperáveis. Enquanto houver civilização com tecnologia relacionada à atual, o esquecimento, a perda, a dissolução total de uma imagem captada e divulgada na internet não tem mais como ser uma garantia. Deste ponto em diante, o controle sobre a reprodução e a edição de imagens não pertence mais ao autor. Isso muda completamente a relação do público com as técnicas, as imagens e as suas relações sociais e 
mercadológicas. A delimitação das esferas de expressão individuais e coletivas perderam a nitidez, e as reflexões impostas pela imagem na cultura digital documentam este processo.

A relevância de uma ação didática na questão da imagem artística, focando a compreensão do desenho e, por extensão, ampliando o conceito de traço para entendermos a sua utilização, está dada na experiência digital diária. Nunca houve tantos experimentos artísticos, com tantos tipos de traços e de tantas origens distintas. Até mesmo para uma ampla fruição de alguns vídeos de arte que são apresentados nas redes sociais seria preciso um repertório cultural específico. Desde as animações das telas de Vincent Van Gogh, onde a gestualidade do traço do artista ganha a dimensão cinematográfica para evidenciar a expressividade da materialidade de sua pintura; passando pela produção de vídeos sobre obras famosas, onde o uso de modelos vivos pintados criam efeitos pictóricos em sequências que evocam a lógica indiciária do traço gerado pelas tintas e as cores usadas pelos artistas; a questão da representação no plano pictórico foi transformada por estes vídeos. Ao construir uma narrativa cinematográfica pela manipulação digital dos elementos plásticos, a leitura das obras do passado não foi apenas alterada, foi estendida.

Entretanto, o trabalho mais curioso que encontrei na internet, relativo a esse aspecto, foi uma reprodução virtual tridimensional da obra "Guernica", de Picasso, que subvertia toda a intenção estética de dramatização das figuras através do plano pictórico. Justamente a planaridade de "Guernica" que, em conjunto com a sua dimensão e a gestualidade das pinceladas de Picasso, seria decisiva para o Expressionismo Abstrato (movimento artístico iniciado em 1940, também conhecido como Escola de Nova Iorque), ganhava no vídeo uma terceira dimensão. Pode parecer uma simples brincadeira tecnológica, mas na realidade trata-se de uma narrativa cultural atual incorporando e recodificando outra, do passado.

Philippe Dubois (1993, p. 258) sentencia que nunca se avaliou suficientemente a importância dos desenvolvimentos tecnológicos para a consciência de tempo e espaço. Cita Paul Virilio (França, 1932), Lissitsky (Rússia, 1890-1941) e Malévitch (Rússia, 1878-1935) para relacionar suas 
imagens artísticas com imagens aéreas e as máquinas que as produziram, a partir do ano de 1914. Impossível não pensar nas narrativas visuais em formação no atual momento tecnológico, quando a sociedade de consumo é alimentada diariamente por registros videográficos de sua realidade. $O$ espetáculo proporcionado pela versatilidade das câmeras GoPro, por exemplo, com sua ótica de lente grande angular, ainda mais quando acopladas nos já populares drones (pequenos aparelhos voadores, com múltiplas hélices, guiados por controle remoto), oferecem ângulos de observação aérea que estruturam novas percepções e narrativas espaciais. São as novas origens tecnológicas dos novos traços do cotidiano, ilustrando as mentes e construindo o imaginário individual e o coletivo.

Compreender uma imagem digital é perceber o mecanismo cultural que a gerou, uma parte fundamental da vivência nos meios de comunicação e informação atuais. Conhecer os processos técnicos digitais, assim como as suas práticas e usos, codificam o olhar e a expressão daqueles que pretendem trabalhar com imagem. $\mathrm{O}$ ato de seleção de imagem fotojornalistica ou artística, em sites, blogs e redes sociais, nos oferecem escolhas com discursos prontos, que dialogam conosco através da tecnologia, replicando e reforçando as imagens escolhidas pelo público como legitimadoras de um dos discursos oferecidos de início. Ter acesso à cultura e ao conhecimento das narrativas artísticas fundamentais da História da Arte, desenvolvendo assim um olhar especializado, é a chave para quebrar o círculo vicioso e adquirir uma visão crítica e independente, em relação às tecnologias e às narrativas visuais da atualidade. Um estudante do Departamento de Artes e Design não pode ficar restrito à compreensão da representação da forma em seu sentido mais primário de semelhança hiperrealista, como acontece hoje. E.H. Gombrich, em seu livro "Meditações sobre um Cavalinho de Pau" (1963), no texto de mesmo título, onde reflete sobre os processos psicológicos de substituição envolvidos na representação, cita Wolfflin quando este afirma que os quadros devem mais aos outros quadros do que à natureza $(\mathrm{H}$. Wolfflin, Principles of Art History, Nova Iorque, 1932). Ou seja, diante das vivências que ilustravam os artistas com os artifícios de representação, na arte do passado analisado por Wolfflin, os canais atuais de construção do conhecimento por meio visual possuem dimensões muito além do observável. A didática deste projeto pedagógico poderia se estender por premissas conceituais sobre a possibilidade de 
uma História da Arte, organizada pela compreensão da origem do traço entendido como índice de realidades culturais - à partir da imagem artística codificada na internet. Contudo, a necessária ação educacional desta proposta é uma primeira e pequena intervenção na realidade automática e compulsória do universo artístico construído pela tecnologia digital. 


\section{Referências Bibliográficas:}

DUBOIS, P. O ato fotográfico e outros ensaios. Campinas: Papirus, 1993.

KRAUSS, R. E. Caminhos da escultura moderna. São Paulo: Martins Fontes, 1998.

PANOFSKY, E. A perspectiva como forma simbólica. Lisboa: Edições 70, 1999.

GREENBERG, C. Arte e cultura. São Paulo: Ática, 1996.

STANGOS N. (Org.). Conceitos da arte moderna. Rio de Janeiro: Jorge Zahar Editor Ltda.,1991.

ARNHEIM, R. Arte e percepção visual. São Paulo: Editora Pioneira, 2000.

KANDINSKY, W. Ponto, Linha, Plano. Lisboa: Edições 70, 1996.

FIEDLER, Konrad. Escritos sobre a Arte. Madrid: Visor, 1991.

MELIA, P.; LUCKHARDT, U. David Hockney. Munique, Londres, Nova Iorque: Prestel Verlag, 2000.

SALUM, F. Unisul. $1^{\circ}$ Seminário Nacional. Discurso, Cultura e Mídia. 2002. PDF em: http://inguagem.unisul.br/paginas/ensino/pos/linguagem/eventos/seminario/anais\%201/F abio_Salun.pdf

PARADELLA, F. A. Teoria da forma - Ponto/Linha/Plano. UNESA. 2011.

http://www.ensp.fiocruz.br/portal-ensp/_uploads/documentos-pessoais/documentopessoal 314.pdf 


\section{Índice de Ilustrações:}

Página 18: Trabalho de Sombra, Caligrafia e Gestualidade. Aula de Desenho de Observação. Anos 2000. Imagem de arquivo pessoal do professor. Fig. 1

Página 19: Trabalho de Sombra, Caligrafia e Gestualidade. Aula de Desenho de Observação. Anos 2000. Imagem de arquivo pessoal do professor. Fig. 2

Página 19: Trabalho de Sombra, Caligrafia e Gestualidade. Aula de Desenho de Observação. Anos 2000. Imagem de arquivo pessoal do professor. Fig. 3

Página 20: Trabalho de Sombra, Caligrafia e Gestualidade. Aula de Desenho de Observação. Anos 2000. Imagem de arquivo pessoal do professor. Fig. 4

Página 20: Trabalho de Sombra, Caligrafia e Gestualidade. Aula de Desenho de Observação. Anos 2000. Imagem de arquivo pessoal do professor. Fig. 5

Página 22: Trabalho de Sombra, Caligrafia e Gestualidade. Aula de Desenho de Observação. Anos 2000. Imagem de arquivo pessoal do professor. Fig. 6

Página 23: Trabalho de Sombra, Caligrafia e Gestualidade. Aula de Desenho de Observação. Anos 2000. Imagem de arquivo pessoal do professor. Fig. 7

Página 24: Trabalho de Sombra, Caligrafia e Gestualidade. Aula de Desenho de Observação. Anos 2000. Imagem de arquivo pessoal do professor. Fig. 8

Página 25: Estudante fazendo o trabalho de Sombra, Caligrafia e Gestualidade durante a aula de Desenho de Observação. Anos 2000. Imagem de arquivo pessoal do professor. Fig. 9

Página 25: Trabalho de Sombra, Caligrafia e Gestualidade. Aula de Desenho de Observação. Anos 2000. Imagem de arquivo pessoal do professor. Fig. 10

Página 27: Trabalho de Sombra, Caligrafia e Gestualidade. Aula de Desenho de Observação. Anos 2000. Imagem de arquivo pessoal do professor. Fig. 11

Página 29: Antonio Pollaiuolo: Hércules e Anteu, c. 1475. Bronze, 45,7 cm. Museo Nazionale, Florença. Reprodução de imagem da internet. Fig. 12 
Página 29: Rodin: Je suis belle, 1882. Bronze, $75 \mathrm{~cm}$ x $40 \mathrm{~cm}$ x 29,5 cm. Museu Rodin, Paris. Reprodução de imagem da internet. Fig. 13

Página 31: Canova: Hércules e Licas, 1812-15 (original, 1796). Mármore, 3,5 m. Galeria de Arte Moderna, Roma. Reprodução de imagem da internet. Fig. 14

Página 32: Trabalho de Fuga da Janela Renascentista. Aula de Desenho de Observação. Anos 2000. Imagem de arquivo pessoal do professor. Fig. 15

Página 35: Trabalho de Fotocolagem. Aula de Desenho de Observação. Anos 2000. Imagem de arquivo pessoal do professor. Fig. 16

Página 35: Trabalho de Fotocolagem. Aula de Desenho de Observação. Anos 2000. Imagem de arquivo pessoal do professor. Fig. 17

Página 46: Mapa Conceitual. Rosa: ação didática. Amarelo: conceitos e textos acadêmicos. Branco: conceitos visuais e processos tecnológicos em transformação e elaboração. Fig. 18 